\title{
Bibliography
}

\section{Primary reading}

Alberti, Leon Battista, On Painting and On Sculpture: The Latin Texts of De Pictura and De Statua, trans. Cecil Grayson (London: Phaidon Press, 1972)

Allott, Robert, Wits Theatre of the Little World (London, 1599)

Anderson, Anthony, 'A Forme of Prayer for Sea Men', in A Godly Sermon (London, 1575)

Antoniszoon, Cornelis, The Safegarde of Saylers, or Great Rutter (London, 1584)

Ascham, Roger, The Scholemaster (London, 1570)

Bacon, Francis, The Philosophical Works of Francis Bacon (Routledge

Revivals), ed. John M. Robertson (Oxford: Routledge, 1905; repr. 2011)

Bate, George, A Short Historical Account of the Rise and Progress of the

Late Troubles in England (London, 1685)

The Bible in English (London, 1568)

The Bible that is, the Holy Scriptures conteined in the Olde and Newe

Testament (London, 1576)

Bourne, William, Inventions or Devises (London, 1590)

Bourne, William, A Regiment for the Sea (London, 1574)

Browne, Thomas, 21st-Century Oxford Authors: Thomas Browne, ed.

Kevin Killeen (Oxford: Oxford University Press, 2014)

Bullinger, Heinrich, Fiftie Godlie and Learned Sermons, trans. H.I. (London, 1577)

Calvin, Jean, The Institution of Christian Religion, trans. Thomas Norton (London, 1561)

Cambrensis, Giraldus, 'The Second Booke the Conquest of Ireland', trans. John Hooker, in The Second Volume of Chronicles: Conteining the Description, Conquest, Inhabitation, and Troblesome Estate of Ireland; First Collected by Raphaell Holinshed (London, 1586) 
Camden, William, Britannia, trans. Philemon Holland (London, 1610)

Camden, William, Camden's Britannia (London, 1695)

Carew, Richard, The Survey of Cornwall (London, 1602)

Chaucer, Geoffrey, The Riverside Chaucer, ed. Larry D. Benson and F.N.

Robinson, 3rd edn (Oxford: Oxford University Press, 1987; repr. 2008)

Clairvaux, Bernard of, Life and Works of Saint Bernard, Abbot of Clairvaux, ed. John Mabillon, ed. and trans. Samuel J. Eales, Vol. IV (London: John Hodges, 1896)

Cortés, Martín, The Arte of Navigation, trans. Richard Eden (London, 1589)

Crooke, Helkiah, Mikrokosmographia: A Description of the Body of Man (London, 1615)

Cuningham, William, The Cosmographical Glasse (London, 1559)

Davies, Sir John, A Discovery of the True Causes, in Ireland Under Elizabeth and James the First, ed. Henry Morley (London: Routledge, 1890), pp. 213-342

Davies, Sir John, 'Sir John Davys to Salisbury', in Calendar of State Papers, Ireland, James I: 1608-1610, ed. Charles W. Russell and John

P. Prendergast (Nendeln: Kraus Reprint, 1974), p. 280

Dee, John, General and Rare Memorials Pertayning to the Perfect Arte of Navigation (London, 1577)

Dee, John, Mathematicall Praeface, in The Elements of Geometrie of the Most Auncient Philosopher Euclide of Megara, trans. Henry Billingsley (London, 1570)

Dering, Edward, A Brief and Necessary Instruction (London, 1572)

Derricke, John, The Image of Irelande (London, 1581)

De Troyes, Chrétien, 'The Knight with the Lion', in The Complete Romances of Chrétien de Troyes, trans. David Staines (Bloomington: Indiana University Press, 1993)

Digges, Leonard and Thomas, A Geometrical Practise, named Pantometria (London, 1571)

Digges, Leonard and Thomas, A Prognostication Everlastinge of Right Good Effecte (London, 1576)

Drayton, Michael, Poly-Olbion, ed. John Selden (London, 1612)

$\mathrm{Du}$ Bellay, Joachim, Les Antiquitez de Rome, in The Regrets, with, The Antiquities of Rome, Three Latin Elegies, and The Defense and Enrichment of the French Language, ed. and trans. Richard Helgerson (Philadelphia: University of Pennsylvania Press, 2006)

Duchesne, Joseph, A Breefe Aunswere of Josephus Quercetanus 
Armeniacus, Doctor of Phisick, to the Exposition of Jacobus Aubertus Vindonis, trans. John Hester (London, 1591)

Dymmok, John, 'A Treatice of Ireland', in Tracts Relating to Ireland, Vol.

II (Dublin: The Irish Archaeological Society, 1843)

Erasmus, Desiderius, Moriae Encomium (Basel, 1515)

Erasmus, Desiderius, The Praise of Folie, trans. Thomas Chaloner (London, 1549)

Fraunce, Abraham, The Third Part of the Countesse of Pembrokes Yuychurch (London, 1592)

Gainsford, Thomas, 'Chapter XVII: The Description of Ireland', in The Glory of England (London, 1618)

Garcie, Pierre, The Rutter of the Sea, trans. Robert Copland (London, 1560)

Gernon, Luke, 'A Discourse of Ireland', in Illustrations of Irish History and Topography, Mainly of the Seventeenth Century, ed. C. Litton Falkiner (London: Longmans, Green, and Co., 1904), pp. $348-62$

Guarino, Battista, 'A Program of Teaching and Learning', in Humanist Educational Treatises, ed. and trans. Craig W. Kallendorf (Cambridge, MA: Harvard University Press, 2002), pp. 260-309

Hakluyt, Richard, The Principall Navigations, Voiages and Discoveries of the English Nation (London, 1589)

Harvey, Gabriel, Three Proper, and Wittie, Familiar Letters (London, 1580)

Hayward, John, A Treatise of Union of the Two Realmes of England and Scotland (London, 1604)

Homer, The Iliad, trans. George Chapman, ed. Adam Roberts (Hertfordshire: Wordsworth, 2003)

Homer, The Odyssey, trans. Robert Fagles (London: Penguin, 2006)

Lhwyd, Humfrey, The Breviary of Britayne, trans. Thomas Twyne (London, 1573)

Lucretius, De Rerum Natura, trans. W.H.D. Rouse (London: William Heinemann, 1924; repr. 1943)

Maley, Willy, "The Supplication of the Blood of the English Most Lamentably Murdered in Ireland, Cryeng out of the Yearth for Revenge (1958)', Analecta Hibernica, 36 (1995), 1-77

Marlowe, Christopher, Hero and Leander (London, 1598)

Mercator, Gerhard, Historia Mundi: Or Mercator's Atlas Containing his Cosmographicall Description of the Fabricke and Figure of the World (London, 1635) 
The Metrical Dindshenchas, trans. Edward Gwynn, 5 vols (Dublin: Hodges Figgis, 1903-1935)

Middleton, Thomas, A Game at Chess, in Women Beware Women and Other Plays, ed. Richard Dutton (Oxford: Oxford University Press, 1999; repr. 2009)

Milton, John, The History of England (London, 1670)

Milton, John, Paradise Lost, ed. Scott Elledge (New York: Norton, 1975) Montaigne, Michel de, The Complete Essays, ed. and trans. M.A. Screech (London: Penguin Books, 1993)

More, Sir Thomas, Utopia, trans. Ralph Robinson (1551), in Three Early Modern Utopias, ed. Susan Bruce (Oxford: Oxford University Press, 1999; repr. 2008), pp. 1-148.

Moryson, Fynes, An Itinerary (London, 1617)

Nashe, Thomas, The Anatomy of Absurdity (London, 1589)

Nashe, Thomas, Nashes Lenten Stuffe (London, 1599)

Nashe, Thomas, Pierce Pennilesse his Supplication to the Devil (London, 1592)

Nashe, Thomas, The Unfortunate Traveller. Or, The Life of Jacke Wilton (London, 1594)

Norden, John, The Surveyors Dialogue (London, 1607)

Ortelius, Abraham, Theatrum Orbis Terrarum, or The Theatre of the Whole World, trans. William Bedwell (London, 1606[08])

Ortúñez de Calahorra, Diego, The Third Part of the First Booke, of the Mirrour of Knighthood, trans. R.P. (London, 1586)

Ovid, Metamorphoses, trans. A.D. Melville (Oxford: Oxford University Press, 1986)

Payne, Robert, A Brief Description of Ireland (London, 1589)

Periegetes, Dionysius, The Surveye of the World, trans. Thomas Twyne (London, 1572)

Plato, Protagoras, trans. Stanley Lombardo and Karen Bell, in Plato: Complete Works, ed. John M. Cooper (Indianapolis: Hackett, 1997), pp. 746-90

Plato, Theaetetus, trans. M.J. Levett and Myles Burnyeat, in Plato: Complete Works, ed. John M. Cooper (Indianapolis: Hackett, 1997), pp. 157-234

Plato, Timaeus, trans. Donald J. Zeyl, in Plato: Complete Works, ed. John M. Cooper (Indianapolis: Hackett, 1997), pp. 1224-91

Ptolemy, Ptolemy's Geography: An Annotated Translation of the Theoretical Chapters, ed. J. Lennart Berggren and Alexander Jones (Princeton: Princeton University Press, 2000) 
Puttenham, George, The Art of English Poesy: A Critical Edition, ed. Frank Whigham and Wayne A. Rebhorn (Ithaca: Cornell University Press, 2007)

Quinn, David B., “'A Discourse of Ireland” (Circa 1599): A Sidelight on English Colonial Policy', Proceedings of the Royal Irish Academy. Section C, 47 (1941/1942), 151-66

Ralegh, Sir Walter, The History of the World (London, 1614 [i.e. 1617])

Ralegh, Sir Walter, The Poems of Sir Walter Ralegh: A Historical Edition, ed. Michael Rudick (Tempe: Arizona Center for Medieval and Renaissance Studies, 1999)

Recorde, Robert, The Pathway to Knowledge (London, 1551)

Rogers, Thomas, The Anatomie of the Minde (London, 1576)

Shakespeare, William, Shakespeare's Sonnets, ed. Katherine DuncanJones (London: Arden Shakespeare, 2010)

Shakespeare, William, The Tempest, ed. Virginia Mason Vaughan and Alden T. Vaughan (London: Thompson, 1999; repr. 2003)

Sidney, Sir Henry, A Viceroy's Vindication? Sir Henry Sidney's Memoir of Service in Ireland 1556-1578, ed. Ciaran Brady (Cork: Cork University Press, 2002)

Sidney, Sir Philip, The Defence of Poesy, in The Oxford Authors: Sir Philip Sidney, ed. Katherine Duncan-Jones (Oxford: Oxford University Press, 1989; repr. 1992), pp. 212-50

Sir Gawain and the Green Knight, ed. J.R.R. Tolkien and E.V. Gordon,

2nd edn revised by Norman Davis (Oxford: Clarendon Press, 1967)

Smith, Sir Thomas, A Letter Sent by I.B. Gentleman (London, 1572)

Spenser, Edmund, Edmund Spenser: The Shorter Poems, ed. Richard A.

McCabe (London: Penguin, 1999)

Spenser, Edmund, The Faerie Queene, ed. A.C. Hamilton, Hiroshi

Yamashita, and Toshiyuki Suzuki (Harlow: Longman, 2001)

Spenser, Edmund, A View of the State of Ireland, ed. Andrew Hadfield and Willy Maley (Oxford: Blackwell, 1997; repr. 1998)

Spenser, Edmund, The Works of Edmund Spenser: A Variorum Edition,

$X$ : The Prose Works, ed. Rudolf Gottfried (Baltimore: Johns Hopkins University Press, 1949)

Stanihurst, Richard, 'A Treastise Conteining a Plaine and Perfect Description of Ireland', in The Second Volume of Chronicles: Conteining the Description, Conquest, Inhabitation, and Troblesome Estate of Ireland; First Collected by Raphaell Holinshed (London, 1586) Turler, Jerome, The Traveiler (London, 1575) 
Vegetius Renatus, Flavius, Du Fait de Guerre (De Re Militari) (Paris, 1536)

Vegetius Renatus, Flavius, The Foure Bookes of Flavius Vegetius Renatus, trans. John Sadler (London, 1572)

Virgil, Eclogues; Georgics; Aeneid I-VI, trans. H. Rushton Fairclough; revised by G.P. Goold (Cambridge, MA: Harvard University Press, 1916; repr. 2006)

Virgil, The Whole .xii. Bookes of the AEneidos of Virgill, trans. Thomas Phaer (London, 1573)

Waghenaer, Lucas Janzoon, The Mariners Mirrour, trans. Anthony Ashley (London, 1588)

Wales, Gerald of, The History and Topography of Ireland, trans. John O’Meara (London: Penguin, 1951; repr. 1988)

Watson, Henry, trans., The Hystorye of Olyver of Castylle (London, 1518) Whitney, Geffrey, A Choice of Emblemes (Leiden, 1586)

Wilson, Thomas, The Rule of Reason, Conteinyng the Arte of Logique (London, 1551)

Worsop, Edward, A Discoverie of Sundrie Errours and Faults Daily Committed by Lande-meaters (London, 1582)

\section{Secondary reading}

Abrams, M.H., The Mirror and the Lamp: Romantic Theory and the Critical Tradition (Oxford: Oxford University Press, 1953; repr. 1976) Akbari, Suzanne Conklin, Seeing Through the Veil: Optical Theory and Medieval Allegory (Toronto: University of Toronto Press, 2004)

Albanese, Denise, New Science, New World (Durham: Duke University Press, 1996)

Alpers, Paul J., 'Narration in The Faerie Queene', ELH, 44.1 (1977), 19-39

Alpers, Paul J., The Poetry of the Faerie Queene (Princeton: Princeton University Press, 1967)

Anderson, Judith H., Reading the Allegorical Intertext: Chaucer, Spenser, Shakespeare, Milton (New York: Fordham University Press, 2008)

Anderson, Miranda, ed., The Book of the Mirror: An Interdisciplinary Collection Exploring the Cultural Story of the Mirror (Newcastle: Cambridge Scholars Press, 2007)

Andrews, J.H., 'The Irish Surveys of Robert Lythe', Imago Mundi, 19 (1965), 22-31

Andrews, J.H., 'Introduction', in J.B. Harley, The New Nature of Maps: 
Essays in the History of Cartography, ed. Paul Laxton (Baltimore: Johns Hopkins University Press, 2001), pp. 1-32

Andrews, J.H., The Queen's Last Map-Maker: Richard Bartlett in Ireland, 1600-3 (Dublin: Geography Publications, 2008)

Andrews, J.H., Shapes of Ireland: Maps and their Makers 1564-1839 (Dublin: Geography Publications, 1997)

Andrews, K.R., Elizabethan Seaman (London: National Maritime Museum, 1982)

Andrews, K.R., N.P. Canny, and P.E.H. Hair, eds, The Westward Enterprise: English Activities in Ireland, the Atlantic and America, 1480-1650 (Liverpool: Liverpool University Press, 1978)

Appelbaum, Robert, 'Anti-Geography', EMLS, 4.2 (1998), 12.1-17

Armitage, Christopher M., ed., Literary and Visual Ralegh (Manchester:

Manchester University Press, 2013)

Armitage, David, 'The Elizabethan Idea of Empire', TRHS, 14 (2004), 269-77

Artese, Charlotte, 'King Arthur in America: Making Space in History for The Faerie Queene and John Dee's Brytanici Imperii Limites', JMEMS, 33.1 (2003), 125-41

Auerbach, Erich, Mimesis: The Representation of Reality in Western Literature, trans. Willard R. Trask (Garden City, NY: Doubleday, 1957)

Avery, Bruce, 'Mapping the Irish Other: Spenser's A View of the Present State of Ireland', ELH, 57.2 (1990), 263-79

Babcock, W.H., 'St. Brendan's Explorations and Islands', Geographical Review, 8.1 (1919), 37-46

Bachelard, Gaston, The Poetics of Space, trans. Maria Jolas (Boston: Beacon, 1964; repr. 1994)

Badcoe, Tamsin, "'The Compasse of that Islands Space”: Insular Fictions in the Writing of Edmund Spenser', Renaissance Studies, 25.3 (2011), 415-32.

Badcoe, Tamsin, 'Mariners, Maps, and Metaphors: Lucas Waghenaer and the Poetics of Navigation', Swiss Papers in English Language and Literature: Medieval and Early Modern Literature, Science and Medicine, 28 (2013), 33-47.

Badcoe, Tamsin, "The Porch of that Enchaunted Gate": Spenserian Influences and the Romance of Place in Lamia by John Keats', Romanticism, 17.3 (2011), 351-64

Baker, David J., 'Charting Uncertainty in Renaissance Ireland', in Representing Ireland: Literature and the Origins of Conflict, 1534- 
1660, ed. Brendan Bradshaw, Andrew Hadfield, and Willy Maley (Cambridge: Cambridge University Press, 1993), pp. 76-92

Bakhtin, Mikhail M., 'Forms of Time and of the Chronotope in the Novel', in The Dialogic Imagination, ed. Michael Holquist, trans. Caryl Emerson and Michael Holquist (Austin: University of Texas Press, 1981; repr. 2002), pp. 84-258

Baldwin, Robert, 'John Dee's Interest in the Application of Nautical Science, Mathematics and Law to English Naval Affairs', in John Dee: Interdisciplinary Studies in English Renaissance Thought, ed. Stephen Clucas (Dordrecht: Springer, 2006), pp. 97-130

Barbour, Reid and Claire Preston, eds, Sir Thomas Browne: The World Proposed (Oxford: Oxford University Press, 2008)

Barnard, John, D.F. McKenzie, and Maureen Bell, eds, The Cambridge History of the Book in Britain Volume 4: 1557-1695 (Cambridge: Cambridge University Press, 2002)

Barnes, Trevor J. and James S. Duncan, eds, Writing Worlds: Discourse, Text, and Metaphor in the Representation of Landscape (London: Routledge, 1992)

Bartolovich, Crystal, “"Baseless Fabric": London as a "World City", in The Tempest and Its Travels, ed. Peter Hulme and William H. Sherman (London: Reaktion, 2000), pp. 13-26

Bate, Jonathan, Romantic Ecology: Wordsworth and the Environmental Tradition (London: Routledge, 1991)

Bates, Catherine, Masculinity and the Hunt: Wyatt to Spenser (Oxford: Oxford University Press, 2013)

Bath, Michael, Speaking Pictures: English Emblem Books and Renaissance Culture (Harlow: Longman, 1994)

Bawarshi, Anis S., Genre and the Invention of the Writer: Reconsidering the Place of Invention in Composition (Logan: Utah State University Press, 2003)

Bednarz, James P., 'The Collaborator as Thief: Ralegh's (Re)Vision of The Faerie Queene', ELH, 63.2 (1996), 279-307

Beer, Anna, “Bellphebes Course is Now Observde No More”: Ralegh,

Spenser and the Literary Politics of the Cynthia Holograph', in Literary and Visual Ralegh, ed. Christopher M. Armitage (Manchester: Manchester University Press, 2013), pp. 140-65

Bellamy, Elizabeth J., Dire Straits: The Perils of Writing the Early Modern English Coastline from Leland to Milton (Toronto: University of Toronto Press, 2013)

Bellamy, Elizabeth J., 'Spenser's Faeryland and “The Curious Genealogy 
of India"', in Worldmaking Spenser: Explorations in the Early Modern Age, ed. Patrick Cheney and Lauren Silberman (Lexington: University Press of Kentucky, 2000), pp. 177-92

Bellamy, Elizabeth J., Translations of Power: Narcissism and the Unconscious in Epic History (Ithaca: Cornell University Press, 1992)

Bender, John B., Spenser and Literary Pictorialism (Princeton: Princeton University Press, 1972)

Benjamin, Walter, The Origin of German Tragic Drama, trans. John Osborne (London: NLB, 1977)

Bennett, Andrew, Ignorance: Literature and Agnoiology (Manchester: Manchester University Press, 2009)

Berger, Jr., Harry, 'Facing Sophists: Socrates' Charismatic Bondage in Protagoras', Representations, 5 (1984), 66-91

Berger, Jr., Harry, Revisionary Play: Studies in the Spenserian Dynamics (Berkeley: University of California Press, 1990)

Berger, Jr., Harry, Second World and Green World: Studies in Renaissance Fiction-making, ed. John Patrick Lynch (Berkeley: University of California Press, 1988)

Berger, Jr., Harry, 'The System of Early Modern Painting', Representations, 62 (1998), 31-57

Berry, Craig A., "'Sundrie Doubts": Vulnerable Understanding and Dubious Origins in Spenser's Continuation of the Squire's Tale', in Refiguring Chaucer in the Renaissance, ed. Theresa M. Krier (Gainesville: University Press of Florida, 1998), pp. 106-27

Berry, Philippa, Of Chastity and Power: Elizabethan Literature and the Unmarried Queen (London: Routledge, 1989)

Berry, Philippa and Margaret Tudeau-Clayton, Textures of Renaissance Knowledge (Manchester: Manchester University Press, 2003)

Betteridge, Thomas, ed., Borders and Travellers in Early Modern Europe (Aldershot: Ashgate, 2007)

Bhabha, Homi K., The Location of Culture (London: Routledge, 1994; repr. 2004)

Bialas, Zbigniew, 'Ambition and Distortion: An Ontological Dimension in Colonial Cartography', in Borderlands: Negotiating Boundaries in Post-Colonial Writing, ed. Monika Reif-Hulser (Amsterdam: Rodopi, 1999), 17-28

Bieman, Elizabeth, Plato Baptized: Towards the Interpretation of Spenser's Mimetic Fictions (Toronto: University of Toronto Press, 1988)

Blick, Fred, 'Spenser's Amoretti and Elizabeth Boyle: Her Names Immortalized', Spenser Studies, 23 (2008), 309-15 
Blissett, William, 'Caves, Labyrinths, and The Faerie Queene', in Unfolded Tales: Essays on Renaissance Romance, ed. George M. Logan and Gordon Teskey (Ithaca: Cornell University Press, 1989), pp. 281-311 Blumenberg, Hans, Shipwreck with Spectator: Paradigm of a Metaphor for Existence, trans. Steven Rendall (Cambridge, MA: MIT Press, 1997)

Booth, Michael, “"Moving on the Waters”: Metaphor and Mental Space in Ralegh's History of the World', in Literary and Visual Ralegh, ed. Christopher M. Armitage (Manchester: Manchester University Press, 2013), pp. 200-16

Borlik, Todd Andrew, 'Caliban and the Fen Demons of Lincolnshire: The Englishness of Shakespeare's Tempest', Shakespeare, 9.1 (2013), 21-51 Borris, Kenneth, Allegory and Epic in English Renaissance Literature: Heroic Forms in Sidney, Spenser and Milton (Cambridge: Cambridge University Press, 2000)

Borris, Kenneth, 'Platonism and Spenser's Poetic: Idealized Imitation, Merlin's Mirror, and the Florimells', Spenser Studies, 24 (2009), 209-68

Borris, Kenneth, Visionary Spenser and the Poetics of Early Modern Platonism (Oxford: Oxford University Press, 2017)

Bottigheimer, Karl S., 'Kingdom and Colony: Ireland in the Westward Enterprise, 1536-1660', in The Westward Enterprise: English Activities in Ireland, the Atlantic and America, 1480-1650, ed. K.R. Andrews, N.P. Canny, and P.E.H. Hair (Liverpool: Liverpool University Press, 1978), pp. 45-64

Braden, Gordon, 'Riverrun: An Epic Catalogue in The Faerie Queene', ELR, 5.1 (1975), 25-48

Bradshaw, Brendan, Andrew Hadfield, and Willy Maley, eds, Representing Ireland: Literature and the Origins of Conflict, 1534-1660 (Cambridge: Cambridge University Press, 1993)

Brady, Ciaran, 'A Brief Note of Ireland', in The Spenser Encyclopedia, ed. A.C. Hamilton (Toronto: University of Toronto Press, 1990), pp. 111-12

Brayton, Dan, Shakespeare's Ocean: An Ecocritical Exploration (Charlottesville: University of Virginia Press, 2012)

Brayton, Dan, 'Shakespeare and Slime: Notes on the Anthropocene', in Ecological Approaches to Early Modern English Texts: A Field Guide to Reading and Teaching, ed. Jennifer Munroe, Edward J. Geisweidt, and Lynne Bruckner (Farnham: Ashgate, 2015), pp. 81-9

Breen, John, 'The Empirical Eye: Edmund Spenser's A View of The Present State of Ireland', The Irish Review, 16 (1994), 44-52 
Breen, John, “Imaginatiue Groundplot": A View of the Present State of Ireland', Spenser Studies, 12 (1998), 151-68

Brückner, Martin and Kristen Poole, 'The Plot Thickens: Surveying Manuals, Drama, and the Materiality of Narrative Form in Early Modern England', ELH, 69 (2002), 617-48

Burlinson, Christopher, Allegory, Space and the Material World in the Writings of Edmund Spenser (Cambridge: D.S. Brewer, 2006)

Burrow, Colin, Epic Romance: Homer to Milton (Oxford: Clarendon, 1993)

Burrow, J.A., “'Sir Thopas”: An Agony in Three Fits', RES, 22 (1971), 54-8

Buisseret, David, The Mapmaker's Quest: Depicting New Worlds in Renaissance Europe (Oxford: Oxford University Press, 2003)

Butler, Chris, "Pricking" and Ambiguity at the Start of The Faerie Queene', Notes and Queries, 55.2 (2008), 159-61

Butlin, R.A., 'Land and People, c. 1600', in A New History of Ireland: Early Modern Ireland 1534-1691, ed. T.W. Moody, F.X. Martin, and F.J. Byrne (Oxford: Oxford University Press, 2009), pp. 142-67

Buttimer, Anne, Geography and the Human Spirit (Baltimore: Johns Hopkins University Press, 1993)

Camino, Mercedes, “"Methinks I See an Evil Lurk Unespied”: Visualizing Conquest in Spenser's A View of the Present State of Ireland', Spenser Studies, 12 (1990), 169-94

Camino, Mercedes, '(Un)folding the Map of Early Modern Ireland: Spenser, Moryson, Bartlett, and Ortelius', Cartographica, 34.4 (1997), $1-17$

Campbell, Marion, 'Inscribing Imperfection: Sir Walter Ralegh and the Elizabethan Court', ELR, 20.2 (1990), 233-53

Campbell, Mary B., The Witness and the Other World: Exotic European Travel Writing, 400-1600 (Ithaca: Cornell University Press, 1988)

Campbell, Mary B., Wonder and Science: Imagining Worlds in Early Modern Europe (Ithaca: Cornell University Press, 1999)

Carey, Daniel, 'Travel and Sexual Fantasy in the Early Modern Period', in Writing and Fantasy, ed. Ceri Sullivan and Barbara White (London: Longman, 1999), pp. 151-65

Carney, James, 'Language and Literature to 1169', in A New History of Ireland, Volume I: Prehistoric and Early Ireland, ed. Dáibhí Ó Cróinín (Oxford: Oxford University Press, 2005), pp. 500-9

Carroll, Clare, 'The Construction of Gender and the Cultural and Political Other in The Faerie Queene 5 and A View of the Present State of Ireland: 
The Critics, The Context, and The Case of Radigund', Criticism, 32.2 (1990), 163-92

Carroll, Clare, 'Spenser and the Irish Language: The Sons of Milesio in A

View of the Present State of Ireland, The Faerie Queene, Book V and the Leabhar Gabhála', IUR, 26.2 (1996), 281-90

Carruthers, Mary, The Book of Memory: A Study of Memory in Medieval Culture (Cambridge: Cambridge University Press, 1990; repr. 2008)

Carruthers, Mary, The Craft of Thought: Meditation, Rhetoric, and the Making of Images, 400-1200 (Cambridge: Cambridge University Press, 1998; repr. 2008)

Carruthers, Mary, ed., Rhetoric Beyond Words: Delight and Persuasion in the Arts of the Middle Ages (Cambridge: Cambridge University Press, 2010)

Carter, Paul, 'Dark with Excess of Bright: Mapping the Coastlines of Knowledge', in Mappings, ed. Denis Cosgrove (London: Reaktion, 1999), pp. 125-47

Carter, Paul, The Road to Botany Bay: An Exploration of Landscape and History (New York: Knopf, 1988)

Cartlidge, Neil, ed., Boundaries in Medieval Romance (Cambridge: D.S. Brewer, 2008)

Casey, Edward S., 'How to Get from Space to Place in a Fairly Short Stretch of Time: Phenomenological Prolegomena', in Senses of Place, ed. Steven Feld and Keith H. Basso (Santa Fe: SAR Press, 1996), pp. 13-52

Cavanagh, Sheila, Wanton Eyes and Chaste Desires (Indianapolis: Indiana University Press, 1994)

Cave, Terence, Recognitions: A Study in Poetics (Oxford: Clarendon Press, 1988)

Cawley, Robert R., Unpathed Waters: Studies in the Influence of the Voyagers on Elizabethan Literature (London: Frank Cass, 1940; repr. 1967)

Cheney, Donald, 'Colin Clout's Homecoming: The Imaginative Travels of Edmund Spenser', Connotations, 7.2 (1997-1998), 146-58

Cheney, Patrick, Reading Sixteenth-Century Poetry (Chichester: WileyBlackwell, 2011)

Cheney, Patrick, “'Secret Powre Unseene”: Good Magic in Spenser's Legend of Britomart', Studies in Philology, 85.1 (1988), 1-28

Cheney, Patrick, 'Spenser's Completion of The Squire's Tale: Love, Magic and Heroic Action in the Legend of Cambell and Triamond', Journal of Medieval and Renaissance Studies, 15 (1985), 135-55 
Cheney, Patrick and Lauren Silberman, eds, Worldmaking Spenser: Explorations in the Early Modern Age (Lexington: University Press of Kentucky, 2000)

Christian, Margaret, "Waves of Weary Wretchedness": Florimell and the Sea', Spenser Studies, 14 (2000), 133-61

Clarke, Catherine A.M., Literary Landscapes and the Idea of England, 700-1400 (Cambridge: D.S. Brewer, 2006)

Clifford, Gay, The Transformations of Allegory (London: Routledge and Kegan Paul, 1974)

Clifford-Amos, Terence, “"Certaine Signes" of "Faeryland": Spenser's Eden of Thanksgiving on the Defeat of the "Monstrous" "Dragon" of Albion's North', Viator, 32 (2001), 371-415

Clucas, Stephen, ed., John Dee: Interdisciplinary Studies in English Renaissance Thought (Dordrecht: Springer, 2006)

Cohen, Adam Max, Shakespeare and Technology: Dramatizing Early Modern Technological Revolutions (New York: Palgrave Macmillan, 2006)

Cohen, Jeffrey Jerome, ed., Prismatic Ecology: Ecotheory Beyond Green (Minneapolis: University of Minnesota Press, 2013)

Coleridge, Samuel Taylor, Coleridge's Miscellaneous Criticism, ed. Thomas Middleton Raysor (London: Constable, 1936)

Coles, Bryony and John, People of the Wetlands: Bogs, Bodies and LakeDwellers (London: Thames and Hudson, 1989)

Comito, Terry, 'Exile and Return in the Greek Romances', Arion, 2.1 (1975), 58-80

Conley, Tom, An Errant Eye: Poetry and Topography in Early Modern France (Minneapolis: University of Minnesota Press, 2011)

Conley, Tom, The Self Made Map: Cartographic Writing in Early Modern France (Minneapolis: University of Minnesota Press, 1996)

Cooper, Helen, The English Romance in Time: Transforming Motifs from Geoffrey of Monmouth to the Death of Shakespeare (Oxford: Oxford University Press, 2004)

Cooper, Helen, 'Romance after 1400', in The Cambridge History of Medieval English Literature, ed. David Wallace (Cambridge: Cambridge University Press, 2002), pp. 690-719

Corbett, Margery and Ronald Lightbown, The Comely Frontispiece: The Emblematic Title-Page in England 1550-1660 (London: Routledge and Kegan Paul, 1979)

Cormack, Lesley B., 'Britannia Rules the Waves? Images of Empire in Elizabethan England', EMLS, 4.2 (1998), 10.1-20 
Cormack, Lesley B., Charting an Empire: Geography at the English Universities, 1580-1620 (Chicago: University of Chicago Press, 1997) Cosgrove, Art, ed., A New History of Ireland, Volume II: Medieval Ireland 1169-1534 (Oxford: Oxford University Press, 2008)

Cosgrove, Denis, Apollo's Eye: A Cartographic Genealogy of the Earth in the Western Imagination (Baltimore: Johns Hopkins University Press, 2001)

Cosgrove, Denis, Geography and Vision: Seeing, Imagining and Representing the World (London: Tauris, 2008)

Cosgrove, Denis, ed., Mappings (London: Reaktion, 1999)

Cosgrove, Denis, 'Prologue: Geography within the Humanities', in Envisioning Landscapes, Making Worlds, ed. Stephen Daniels, Dydia DeLyser, J. Nicholas Entrikin, and Douglas Richardson (Oxford: Routledge, 2011), pp. xxii-xxv

Cosgrove, Denis and Stephen Daniels, eds, The Iconography of Landscape: Essays on the Symbolic Representation, Design and Use of Past Environments (Cambridge: Cambridge University Press, 1988)

Coughlan, Patricia, 'The Local Context of Mutabilitie's Plea', IUR, 26.2 (1996), 320-41

Crane, Mary Thomas, 'Analogy, Metaphor and the New Science: Cognitive Science and Early Modern Epistemology', in Introduction to Cognitive Cultural Studies, ed. Lisa Zunshine (Baltimore: Johns Hopkins University Press, 2010), pp. 103-14

Crane, Mary Thomas, 'Surface, Depth, and the Spatial Imaginary: A Cognitive Reading of The Political Unconscious', Representations, 108.1 (2009), 76-97

Cresswell, Tim, On the Move: Mobility in the Modern Western World (New York: Routledge, 2006)

Cummings, R.M., Spenser: The Critical Heritage (London: Routledge and Kegan Paul, 1971)

Curry, Michael R., The Work in the World: Geographical Practice and the Written Word (Minneapolis: University of Minnesota Press, 1996)

Curtius, Ernst Robert, European Literature and the Latin Middle Ages, trans. Willard R. Trask (London: Routledge and Kegan Paul, 1953)

Daniels, Stephen, 'Geographical Imagination', Transactions of the Institute of British Geographers, 36.2 (2011), 182-7

Daniels, Stephen, Dydia DeLyser, J. Nicholas Entrikin, and Douglas Richardson, eds, Envisioning Landscapes, Making Worlds: Geography and the Humanities (Oxford: Routledge, 2011) 
Das, Santanu, Touch and Intimacy in First World War Literature (Cambridge: Cambridge University Press, 2008)

Davis, Nick, Stories of Chaos: Reason and its Displacement in Early Modern English Narrative (Aldershot: Ashgate, 1999)

Dawson, Lesel, Lovesickness and Gender in Early Modern English Literature (Oxford: Oxford University Press, 2008)

Deacon, Richard, John Dee: Scientist, Geographer, Astrologer and Secret Agent to Elizabeth I (London: Frederick Muller, 1968)

De Certeau, Michel, The Practice of Everyday Life, trans. Steven Rendall (Berkeley: University of California Press, 1984)

Dees, Jerome S., 'Colin Clout and the Shepherd of the Ocean', Spenser Studies, 15 (2001), 185-95

Dees, Jerome S., 'The Narrator of The Faerie Queene: Patterns of Response', Texas Studies in Literature and Language, 12.4 (1971), 537-68

Dees, Jerome S., 'The Ship Conceit in The Faerie Queene: "Conspicuous Allusion" and Poetic Structure', Studies in Philology, 72 (1975), 208-25 De Girolami Cheney, Liana, 'Giorgio Vasari's The Toilet of Venus: Neoplatonic Notion of Female Beauty', in Neoplatonism and Western Aesthetics, ed. Aphrodite Alexandrakis and Nicholas J. Moutafakis (Albany: State University of New York Press, 2002), pp. 99-112

De Grummond, Nancy Thomson, Etruscan Myth, Sacred History, and Legend (Philadelphia: University of Pennsylvania Museum of Archaeology and Anthropology, 2006)

Deleuze, Gilles, Desert Islands and Other Texts, 1953-1974, ed. David Lapoujade, trans. Michael Taormina (Cambridge, MA: Semiotext(e), 2004)

DeNeef, A. Leigh, 'Timias', in The Spenser Encyclopedia, ed. A.C. Hamilton (Toronto: University of Toronto Press, 1990), pp. 690-1

Dening, Greg, 'Deep Times, Deep Spaces', in Sea Changes: Historicizing the Ocean, ed. Bernhard Klein and Gesa Mackenthun (New York: Routledge, 2004), pp. 13-35

Demaray, John G., Cosmos and Epic Representation: Dante, Spenser, Milton and the Transformation of Renaissance Heroic Poetry (Pittsburgh: Duquesne University Press, 1991)

Dixon, Sandra Lee, Augustine: The Scattered and Gathered Self (St Louis, Missouri: Chalice Press, 1999)

Dobin, Howard, Merlin's Disciples: Prophecy, Poetry, and Power in Renaissance England (Stanford: Stanford University Press, 1990) Dobranski, Stephen B., Readers and Authorship in Early Modern England (Cambridge: Cambridge University Press, 2005) 
Dolven, Jeff, Scenes of Instruction in Renaissance Romance (Chicago: University of Chicago Press, 2007)

Doob, Penelope Reed, The Idea of the Labyrinth from Classical Antiquity through the Middle Ages (Ithaca: Cornell University Press, 1990)

Doody, Margaret Anne, 'Marshes, Shores and Muddy Margins', in The True Story of the Novel (New Brunswick: Rutgers University Press, 1996), pp. 319-36

Dorrian, Mark, 'On Some Spatial Aspects of the Colonial Discourse on Ireland', The Journal of Architecture, 6.1 (2001), 27-51

Douglas, Mary, Purity and Danger: An Analysis of Concept of Pollution and Taboo (London: Routledge, 2002)

Dubrow, Heather, "A Doubtful Sense of Things": Thievery in The Faerie Queene 6.10-6.11', in Worldmaking Spenser: Explorations in the Early Modern Age, ed. Patrick Cheney and Lauren Silberman (Kentucky: University Press of Kentucky, 2000), pp. 204-16

Duckert, Lowell, 'The Slough of Respond', O-Zone: A Journal of ObjectOrientated Studies, 1 (2014), 110-17

Duckert, Lowell, 'Water Ralegh's Liquid Narrative: The Discoverie of Guiana', in Literary and Visual Ralegh, ed. Christopher M. Armitage (Manchester: Manchester University Press, 2013), pp. 217-41

Duffy, Eamon, The Stripping of the Altars: Traditional Religion in England, c. 1400-c. 1580 (New Haven: Yale University Press, 1992)

Duncan, James and David Ley, eds, Place / Culture / Representation (London: Routledge, 1993)

Duncan, James and Derek Gregory, eds, Writes of Passage: Reading Travel Writing (London: Routledge, 1999)

Duncan-Jones, Katherine, 'The Date of Raleigh's "21th: And Last Booke of the Ocean to Scinthia"', RES, 21 (1970), 143-58

Dyas, Dee, Pilgrimage in Medieval English Literature 700-1500 (Cambridge: D.S. Brewer, 2001)

Edgerton, Jr., Samuel Y., The Renaissance Rediscovery of Linear Perspective (New York: Harper and Row, 1975; repr. 1976)

Edwards, A.S.G., 'The Manuscript: British Library MS Cotton Nero A.x', in A Companion to the Gawain-Poet, ed. Derek Brewer and Jonathan Gibson (Cambridge: D.S. Brewer, 1997), 197-219

Edwards, Jess, Writing, Geometry and Space in Seventeenth-Century England and America: Circles in the Sand (London: Routledge, 2006)

Edwards, Philip, Pilgrimage and Literary Tradition (Cambridge: Cambridge University Press, 2006) 
Edwards, Philip, Sea-Mark: The Metaphorical Voyage, Spenser to Milton (Liverpool: Liverpool University Press, 1997)

Edwards, Philip, Sir Walter Ralegh (London: Longmans, Green, 1953)

Eggert, Katherine, Disknowledge: Literature, Alchemy, and the End of Humanism in Renaissance England (Philadelphia: University of Pennsylvania Press, 2015)

Eklund, Hillary, 'Wetlands Reclamation and the Fate of the Local in Seventeenth-Century England', in Groundwork: English Renaissance Literature and Soil Science (Pittsburgh: Duquesne University Press, 2017), pp. 149-70

Eliade, Mircea, The Sacred and the Profane: The Nature of Religion, trans. Willard R. Trask (New York: Harper, 1957; repr. 1959)

Elkins, James, The Poetics of Perspective (Ithaca: Cornell University Press, 1994; repr. 1996)

Elliot, R.W.V., The Gawain Country (Ilkley: University of Leeds, 1984)

Ellrodt, Robert, Neoplatonism in the Poetry of Spenser (Geneva: E. Droz, 1960)

Enterline, Lynn, The Rhetoric of the Body from Ovid to Shakespeare (Cambridge: Cambridge University Press, 2000)

Erickson, Wayne, Mapping The Faerie Queene: Quest Structures and the World of the Poem (New York: Garland, 1996)

Erickson, Wayne, 'Spenser Reads Ralegh's Poetry in(to) the 1590 Faerie Queene', Spenser Studies, 15 (2001), 175-84

Escobedo, Andrew, Nationalism and Historical Loss in Renaissance England (Ithaca: Cornell University Press, 2004)

Ferguson, Margaret W., 'Saint Augustine's Region of Unlikeness: The Crossing of Exile and Language', in Innovations of Antiquity, ed. Ralph Hexter and Daniel Selden (London: Routledge, 1992), pp. 69-94

Fewster, Carol, Traditionality and Genre in Middle English Romance (Cambridge: D.S. Brewer, 1987)

Fichter, Andrew, Poets Historical: Dynastic Epic in the Renaissance (New Haven: Yale University Press, 1982)

Field, Rosalind, 'The King Over the Water: Exile-and-Return Revisited', in Cultural Encounters in the Romance of Medieval England, ed. Corinne Saunders (Cambridge: D.S. Brewer, 2005), pp. 41-53

Fitter, Chris, Poetry, Space, Landscape: Toward a New Theory (Cambridge: Cambridge University Press, 1995)

Fitzpatrick, Joan, Irish Demons: English Writings on Ireland, the Irish, and Gender by Spenser and his Contemporaries (Lanham: University Press of America, 2000) 
Fitzpatrick, Joan, 'Marrying Waterways: Politicizing and Gendering the Landscape', in Archipelagic Identities: Literature and Identity in the Atlantic Archipelago, 1550-1800, ed. Philip Schwyzer and Simon Mealor (Aldershot: Ashgate, 2004), pp. 81-91

Fleck, Andrew, 'Early Modern Marginalia in Spenser's Faerie Queene at the Folger', Notes and Queries, 55.2 (2008), 165-70

Fletcher, Angus, Allegory: The Theory of a Symbolic Mode (Ithaca: Cornell University Press, 1964)

Fletcher, Angus, The Prophetic Moment: An Essay on Spenser (Chicago: University of Chicago Press, 1971)

Fletcher, Angus, Time, Space, and Motion in the Age of Shakespeare (Cambridge, MA: Harvard University Press, 2007)

Flint, Valerie I.J., The Imaginative Landscape of Christopher Columbus (Princeton: Princeton University Press, 1992)

Floyd-Wilson, Mary, English Ethnicity and Race in Early Modern Drama (Cambridge: Cambridge University Press, 2003)

Floyd-Wilson, Mary, 'Transmigrations: Crossing Regional and Gender Boundaries in Antony and Cleopatra', Enacting Gender on the English Renaissance Stage, ed. Viviana Comensoli and Anne Russell (Chicago: University of Illinois Press, 1999), pp. 73-96

Floyd-Wilson, Mary and Garrett A. Sullivan, Jr., eds, Environment and Embodiment in Early Modern England (Basingstoke: Palgrave Macmillan, 2007)

Fludernik, Monika, Towards a 'Natural' Narratology (London: Routledge, 1996)

Fogarty, Anne, 'The Colonisation of Language', in Spenser and Ireland: An Interdisciplinary Perspective, ed. Patricia Coughlan (Cork: Cork University Press, 1989), pp. 74-108

Fogarty, Anne, 'Narrative Strategy in The Faerie Queene, Book VI', in Edmund Spenser, ed. Andrew Hadfield (London: Longman, 1996), pp. 196-210

Foucault, Michel, 'Of Other Spaces', trans. Jay Miskowiec, Diacritics, 16.1 (1986), 22-7

Fowler, Alastair, Renaissance Realism: Narrative Images in Literature and Art (Oxford: Oxford University Press, 2003; repr. 2009)

Fowler, Alastair, 'The River Guyon', MLN, 75.4 (1960), 289-92

French, Peter J., John Dee: The World of an Elizabethan Magus (London:

Routledge and Kegan Paul, 1972)

Fried, Debra, 'Spenser's Caesura', ELR, 11.3 (1981), 261-80 
Fruen, Jeffrey P., 'The Faery Queen Unveiled? Five Glimpses of Gloriana', Spenser Studies, 11 (1994), 53-87

Frye, Northrop, The Secular Scripture: A Study of the Structure of Romance (Cambridge, MA: Harvard University Press, 1976)

Fuchs, Barbara, 'Conquering Islands: Contextualizing The Tempest', SQ, 48.1 (1997), 45-62

Fuchs, Barbara, Romance (New York: Routledge, 2004)

Fuller, Mary C., 'Ralegh's Fugitive Gold: Reference and Deferral in The Discoverie of Guiana', Representations, 33.1 (1991), 42-64

Fuller, Mary C., Voyages in Print: English Travel to America, 1576-1624 (Cambridge: Cambridge University Press, 1995)

Galbraith, David, Architectonics of Imitation in Spenser, Daniel, and Drayton (Toronto: University of Toronto Press, 2000)

Genette, Gérard, Paratexts: Thresholds of Interpretation, trans. Jane E. Lewin (Cambridge: Cambridge University Press, 1997)

Giamatti, A. Bartlett, Exile and Change in Renaissance Literature (New Haven: Yale University Press, 1984)

Giblett, Rod, Postmodern Wetlands: Culture, History, Ecology (Edinburgh: Edinburgh University Press, 1996)

Gillies, John, Shakespeare and the Geography of Difference (Cambridge: Cambridge University Press, 1994)

Gillingham, John, 'The English Invasion of Ireland', in Representing Ireland: Literature and the Origins of Conflict, 1534-1660, ed. Brendan Bradshaw, Andrew Hadfield, and Willy Maley (Cambridge: Cambridge University Press, 1993), pp. 24-42

Gillis, John R., Islands of the Mind: How the Human Imagination Created the Atlantic World (New York: Palgrave Macmillan, 2004)

Gillis, John R., 'Not Continents in Miniature: Islands as Ecotones', Island Studies Journal, 9.1 (2014), 155-66

Ginzburg, Carlo, Clues, Myths, and the Historical Method, trans. John and Anne C. Tedeschi (Baltimore: Johns Hopkins University Press, 1989)

Goldberg, Benjamin, The Mirror and Man (Charlottesville: University of Virginia Press, 1985)

Goldberg, Jonathan, Endlesse Worke: Spenser and the Structures of Discourse (Baltimore: Johns Hopkins University Press, 1981)

Goodman, Jennifer R., Chivalry and Exploration 1298-1630 (Woodbridge: Boydell Press, 1998)

Goodman, Nelson, Ways of Worldmaking (Hassocks: Harvester, 1978) 
Gordon, Andrew and Bernhard Klein, eds, Literature, Mapping and the Politics of Space in Early Modern Britain (Cambridge: Cambridge University Press, 2001)

Gottfried, Rudolf, 'Irish Geography in Spenser's View', ELH, 6.2 (1939), 114-37

Grabes, Herbert, The Mutable Glass: Mirror-Imagery in Titles and Texts of the Middle Ages and English Renaissance, trans. Gordon Collier (Cambridge: Cambridge University Press, 1973; repr. 1982)

Graham, Brian J., and Lindsay J. Proudfoot, eds, An Historical Geography of Ireland (London: Academic Press, 1993)

Greenblatt, Stephen, Renaissance Self-Fashioning from More to Shakespeare (Chicago: University of Chicago Press, 1980)

Greenblatt, Stephen, Sir Walter Ralegh: The Renaissance Man and His Roles (New Haven: Yale University Press, 1973)

Greene, Roland, Five Words: Critical Semantics in the Age of Shakespeare and Cervantes (Chicago: University of Chicago Press, 2013)

Greene, Roland, 'Island Logic', in The Tempest and Its Travels, ed. Peter Hulme and William H. Sherman (London: Reaktion, 2000), pp. 138-45 Greene, Roland, 'A Primer of Spenser's Worldmaking: Alterity in the Bower of Bliss', in Worldmaking Spenser: Explorations in the Early Modern Age, ed. Patrick Cheney and Lauren Silberman (Lexington: University Press of Kentucky, 2000), pp. 9-31

Greene, Roland, "The "Scriene" and the Channel: England and Spain in Book V of The Faerie Queene', JMEMS, 39.1 (2009), 43-64

Greene, Roland, Unrequited Conquests: Love and Empire in the Colonial Americas (Chicago: University of Chicago Press, 1999)

Gregerson, Linda, 'Protestant Erotics: Idolatry and Interpretation in Spenser's Faerie Queene', ELH, 58.1 (1991), 1-34

Gregerson, Linda, The Reformation of the Subject: Spenser, Milton, and the English Protestant Epic (Cambridge: Cambridge University Press, 1995)

Gregerson, Linda, 'Spenser's Georgic: Violence and the Gift of Place', Spenser Studies, 22 (2007), 185-201

Gregerson, Linda, 'Telling Time: Temporality in The Faerie Queene', Hugh MacClean Memorial Lecture, International Spenser Society, 7 January 2012, Spenser Review, 42.7

Gregory, Derek, 'Imaginative Geographies', Progress in Human Geography, 19.4 (1995), 447-85

Grenfell, Joanne Woolway, 'Do Real Knights Need Maps? Charting Moral, Geographical and Representational Uncertainty in Edmund 
Spenser's The Faerie Queene', in Literature, Mapping and the Politics of Space in Early Modern Britain, ed. Andrew Gordon and Bernhard Klein (Cambridge: Cambridge University Press, 2001), pp. 224-38 Grenfell, Joanne Woolway, 'Significant Spaces in Edmund Spenser's View of the Present State of Ireland', EMLS, 4.2 (1998), 6.1-21

Grennan, Eamon, 'Language and Politics: A Note on Some Metaphors in Spenser's A View of the Present State of Ireland', Spenser Studies, 3 (1982), 99-110

Griffith, Gareth, 'Merlin', in Heroes and Anti-Heroes in Medieval Romance, ed. Neil Cartlidge (Cambridge: D.S. Brewer, 2012)

Gross, Kenneth, 'Green Thoughts in a Green Shade', Spenser Studies, 24 (2009), 355-71

Gross, Kenneth, 'The Postures of Allegory', in Edmund Spenser: Essays on Culture and Allegory, ed. Jennifer Klein Morrison and Matthew Greenfield (Aldershot: Ashgate, 2000), pp. 167-79

Gross, Kenneth, Spenserian Poetics: Idolatry, Iconoclasm, and Magic (Ithaca: Cornell University Press, 1985)

Guenther, Genevieve Juliette, Magical Imaginations: Instrumental Aesthetics in the English Renaissance (Toronto: University of Toronto Press, 2012)

Gwynn, Edward, The Metrical Dindshenchas: General Introduction to the Dindshenchas, Vol. 5 (Dublin: Hodges Figgis, 1935)

Hadfield, Andrew, 'Another Look at Serena and Irena', IUR, 26.2 (1996), 291-302

Hadfield, Andrew, Edmund Spenser (London: Longman, 1996)

Hadfield, Andrew, Edmund Spenser: A Life (Oxford: Oxford University Press, 2012; repr. 2014)

Hadfield, Andrew, Edmund Spenser's Irish Experience: Wilde Fruit and Salvage Soyl (Oxford: Clarendon: 1997)

Hadfield, Andrew, Literature, Politics and National Identity: Reformation to Renaissance (Cambridge: Cambridge University Press, 1994)

Hadfield, Andrew, Shakespeare, Spenser and the Matter of Britain (Basingstoke: Palgrave Macmillan, 2004)

Hadfield, Andrew and Willy Maley, 'Introduction: Irish Representations and English Alternatives', in Representing Ireland: Literature and the Origins of Conflict, 1534-1660, ed. Brendan Bradshaw, Andrew Hadfield, and Willy Maley (Cambridge: Cambridge University Press, 1993), pp. 1-23

Hadot, Pierre, What is Ancient Philopsophy?, trans. Michael Chase (Cambridge, MA: Harvard University Press, 2004) 
Halliwell, James Orchard, ed., The Private Diary of Dr. John Dee and the Catalogue of His Library of Manuscripts (London: Camden Society, 1842)

Hamilton, A.C., 'Our New Poet: Spenser, "Well of English Undefyled"', in A Theatre for Spenserians, ed. Judith M. Kennedy and James A. Reither (Manchester: Manchester University Press, 1973), pp. 101-23 Hamilton, A.C., ed., The Spenser Encyclopedia (Toronto: University of Toronto Press, 1990)

Hamilton, A.C., The Structure of Allegory in The Faerie Queene (Oxford: Clarendon, 1961)

Hankins, James, Plato in the Italian Renaissance, Vol. 1 (Leiden: Brill, 1990)

Hankins, John Erskine, Source and Meaning in Spenser's Allegory: A Study of The Faerie Queene (Oxford: Clarendon Press, 1971)

Haraway, Donna, 'Situated Knowledges: The Science Question in Feminism and the Privilege of Partial Perspective', Feminist Studies, 14.3 (1988), 575-99

Hardie, Philip R., The Last Trojan Hero: A Cultural History of Virgil's Aeneid (London: I.B. Taurus, 2014)

Hardie, Philip R., Virgil's Aeneid: Cosmos and Imperium (Oxford: Clarendon Press, 2003)

Harley, J.B., 'Deconstructing the Map', in Writing Worlds: Discourse, Text, and Metaphor in the Representation of Landscape, ed. Trevor J. Barnes and James S. Duncan (London: Routledge, 1992), pp. 231-47 Harley, J.B., The New Nature of Maps: Essays in the History of Cartography, ed. Paul Laxton (Baltimore: Johns Hopkins University Press, 2001)

Harrington, John P., The English Traveller in Ireland: Accounts of Ireland and the Irish through Five Centuries (Dublin: Wolfhound Press, 1991) Harvey, P.D.A., Maps in Tudor England (London: Public Record Office and the British Library, 1993)

Hazlitt, William, 'Lecture II: On Chaucer and Spenser', in Lectures on the English Poets (London: Taylor and Hessey, 1818), pp. 39-85

Heale, Elizabeth, 'Travailing Abroad: The Poet as Adventurer', in Travels and Translations in the Sixteenth Century, ed. Mike Pincombe (Aldershot: Ashgate, 2004), pp. 3-18

Heaney, Seamus, Preoccupations: Selected Prose, 1968-1978 (London: Faber, 1980)

Hecht, Paul J. and J.B. Lethbridge, eds, Spenser in the Moment (Madison:

Fairleigh Dickinson University Press, 2015)

Helgerson, Richard, 'The Folly of Maps and Modernity', in Literature, 
Mapping and the Politics of Space in Early Modern Britain, ed. Andrew Gordon and Bernhard Klein (Cambridge: Cambridge University Press, 2001), pp. 241-62

Helgerson, Richard, Forms of Nationhood: The Elizabethan Writing of England (Chicago: University of Chicago Press, 1992)

Heng, Geraldine, Empire of Magic: Medieval Romance and the Politics of Cultural Fantasy (New York: Columbia University Press, 2003)

Heninger, Jr., S.K., The Cosmographical Glass: Renaissance Diagrams of the Universe (San Marino: Huntington Library, 1977; repr. 2004)

Heninger, Jr., S.K., A Handbook of Renaissance Meteorology (Durham, NC: Duke University Press, 1960)

Heninger, Jr., S.K., Touches of Sweet Harmony: Pythagorean Cosmology and Renaissance Poetics (San Marino: Huntington Library, 1974) Henley, Pauline, Spenser in Ireland (Cork: Cork University Press, 1928) Herron, Thomas, "'Goodly Woods": Irish Forests, Georgic Trees in Books 1 and 4 of Edmund Spenser's Faerie Queene', Quidditas, 19 (1998), 97-122

Herron, Thomas, 'Irish Den of Thieves: Souterrains (and a Crannog?) in Books V and VI of Spenser's Faerie Queene', Spenser Studies, 14 (2000), 303-17

Herron, Thomas, 'Irish Romance: Spenser's Prince Arthur and the Hystorye of Olyuer of Castile (c. 1518)', Notes and Queries, 51.3 (2004), 254-6

Herron, Thomas, 'Love's "Emperye": Raleigh's "Ocean to Scinthia," Spenser's "Colin Clouts Come Home Againe" and The Faerie Queene IV.vii in Colonial Context', in Literary and Visual Ralegh, ed. Christopher M. Armitage (Manchester: Manchester University Press, 2013), pp. 100-39

Herron, Thomas, 'New English Nation: Munster Politics, Virgilian Complaint, and Pastoral Empire in Spenser's "Colin Clouts Come Home Againe” (1595)', Eolas, 8 (2015), 89-122

Herron, Thomas, 'Orpheus in Ulster: Richard Bartlett's Colonial Art', in Ireland in the Renaissance, c. 1540-1660, ed. Thomas Herron and Michael Potterton (Dublin: Four Courts Press, 2007), pp. 289-308

Herron, Thomas, 'The Spanish Armada, Ireland, and Spenser's The Faerie

Queene', New Hibernia Review, 6.2 (2002), 82-105

Herron, Thomas, Spenser's Irish Work: Poetry, Plantation and Colonial Reformation (Aldershot: Ashgate, 2007)

Herron, Thomas and Michael Potterton, eds, Ireland in the Renaissance, c. 1540-1660 (Dublin: Four Courts Press, 2007) 
Hieatt, A. Kent, Chaucer, Spenser, Milton: Mythopoeic Continuities and Transformations (Montreal: McGill-Queen's University Press, 1975)

Hieatt, A. Kent, 'Room of One's Own for Decisions: Chaucer and The Faerie Queene', in Refiguring Chaucer in the Renaissance, ed. Theresa M. Krier (Gainesville: University Press of Florida, 1998), pp. 147-64

Highley, Christopher, Shakespeare, Spenser and the Crisis in Ireland (Cambridge: Cambridge University Press, 1997)

Hile, Rachel E., 'The Limitations of Concord in the Thames-Medway Marriage Canto of The Faerie Queene', Studies in Philology, 108.1 (2011), 70-85

Hughes, Merritt Y., 'Spenser's Acrasia and the Circe of the Renaissance', Journal of the History of Ideas, 4 (1943), 381-99

Honig, Edwin, Dark Conceit: The Making of Allegory (Providence: Brown University Press, 1959; repr. 1972)

Horner, Joyce, 'The Large Landscape: A Study of Certain Images in Ralegh', Essays in Criticism, 5.3 (1955), 197-213

Houston, Chloë, ed., New Worlds Reflected: Travel and Utopia in the Early Modern Period (Farnham: Ashgate, 2010)

Howarth, William L., 'Imagined Territory: The Writing of Wetlands', NLH, 30.3 (1999), 509-39

Hulme, Peter and William H. Sherman, eds, The Tempest and Its Travels (London: Reaktion, 2000)

Hurd, Barbara, Stirring the Mud: On Swamps, Bogs, and Human Imagination (Boston: Beacon Press, 2001)

Hurd, Bishop Richard, Hurd's Letters on Chivalry and Romance, ed. Edith J. Morley (London: Henry Frowde, 1911)

Hutson, Lorna, 'Chivalry for Merchants; or, Knights of Temperance in the Realms of Gold', JMEMS, 26.1 (1996), 29-59

Hutson, Lorna, 'Fortunate Travellers: Reading for the Plot in SixteenthCentury England', Representations, 41 (1993), 83-103

Iser, Wolfgang, The Act of Reading: A Theory of Aesthetic Response (Baltimore: Johns Hopkins University Press, 1978; repr. 1994)

Jameson, Fredric, 'Magical Narratives: Romance as Genre', NLH, 7.1 (1975), 135-63

Jerram, Leif, 'Space: A Useless Category for Historical Analysis?', History and Theory, 52.3 (2013), 400-19

Johnson, William C., Spenser's Amoretti: Analogies of Love (Lewisburg:

Bucknell University Press, 1990)

Joyce, Patrick Weston, 'Spenser's Irish Rivers', in The Wonders of Ireland 
and Other Papers on Irish Subjects (London: Longmans, Green, and Co., 1911), pp. 72-114

Judson, Alexander Corbin, Spenser in Southern Ireland (Bloomington:

Principia Press, 1933)

Justice, Steven, 'Literary History and Piers Plowman', in The Cambridge

Companion to Piers Plowman, ed. Andrew Cole and Andrew Galloway

(Cambridge: Cambridge University Press, 2014), pp. 50-64

Kalas, Rayna, Frame, Glass, Verse: The Technology of Poetic Invention in the English Renaissance (Ithaca: Cornell University Press, 2007)

Kantorowicz, Ernst H., The King's Two Bodies: A Study in Mediaeval

Political Theology (Princeton: Princeton University Press, 1957)

Keighren, Innes M., 'Geosophy, Imagination, and Terrae Incognitae:

Exploring the Intellectual History of John Kirtland Wright', Journal of Historical Geography, 31.3 (2005), 546-56

Kendrick, Walter M., 'Earth of Flesh, Flesh of Earth: Mother Earth in The Faerie Queene', RQ, 27.4 (1974), 533-48

Kermode, Frank, The Sense of an Ending: Studies in the Theory of Fiction (Oxford: Oxford University Press, 1967; repr. 1977)

Kerrigan, John, Archipelagic English: Literature, History, and Politics, 1603-1707 (Oxford: Oxford University Press, 2008)

Killeen, Kevin, Biblical Scholarship, Science and Politics in Early Modern England: Thomas Browne and the Thorny Place of Knowledge (Aldershot: Ashgate, 2009)

King, Andrew, The Faerie Queene and Middle English Romance: The Matter of Just Memory (Oxford: Clarendon, 2000)

King, Andrew, "'Well Grounded, Finely Framed, and Strongly Trussed up Together": The "Medieval" Structure of The Faerie Queene', in Edmund Spenser: New and Renewed Directions, ed. J.B. Lethbridge (Madison: Fairleigh Dickinson University Press, 2006), pp. 119-52

Kinzel, Ulrich, 'Orientation as a Paradigm of Maritime Modernity', in Fictions of the Sea: Critical Perspectives on the Ocean in British Literature and Culture, ed. Bernhard Klein and Gesa Mackenthun (Aldershot: Ashgate, 2002), pp. 28-48

Kitch, Aaron, Political Economy and the States of Literature in Early Modern England (Farnham: Ashgate, 2009)

Klein, Bernhard, 'Imaginary Journeys: Spenser, Drayton, and the Poetics of National Space', in Literature, Mapping and the Politics of Space in Early Modern Britain, ed. Andrew Gordon and Bernhard Klein (Cambridge: Cambridge University Press, 2001), pp. 204-23 
Klein, Bernhard, 'The Lie of the Land: English Surveyors, Irish Rebels and The Faerie Queene', IUR, 26.2 (1996), 207-25

Klein, Bernhard, 'Mapping the Waters: Sea Charts, Navigation, and Camões's Os Lusíadas', Renaissance Studies, 25.2 (2011), 228-47

Klein, Bernhard, Maps and the Writing of Space in Early Modern England and Ireland (Basingstoke: Palgrave Macmillan, 2001)

Klein, Bernhard, 'Partial Views: Shakespeare and the Map of Ireland', EMLS, 4.2 (1998), 5.1-20

Klein, Naomi Reed, Maps of Medieval Thought: The Hereford Paradigm (Woodbridge: Boydell Press, 2001)

Knapp, James A., Image Ethics in Shakespeare and Spenser (New York: Palgrave Macmillan, 2011)

Knapp, Jeffrey, An Empire Nowhere: England, America, and Literature from Utopia to The Tempest (Berkeley: University of California Press, 1992)

Knight, Stephen, Merlin: Knowledge and Power Through the Ages (Ithaca: Cornell University Press, 2009)

Koeman, Cornelis, The History of Lucas Janszoon Waghenaer and his Spieghel der Zeevaerdt (Lausanne: Sequoia, 1964)

Koyré, Alexandre, From the Closed World to the Infinite Universe (Baltimore: Johns Hopkins University Press, 1957)

Krier, Theresa M., Refiguring Chaucer in the Renaissance (Gainesville: University Press of Florida, 1998)

Lachavanne, Jean-Bernard and Raphaëlle Juge, eds, Biodiversity in LandInland Water Ecotones (Paris: UNESCO; New York and Carnforth: Parthenon, 1997)

Lakoff, George and Mark Johnson, Metaphors We Live By (Chicago: University of Chicago Press, 1980)

Lambert, Ladina Bezzola, Imagining the Unimaginable: The Poetics of Early Modern Astronomy (Amsterdam: Rodopi, 2002)

Lee, Judith, 'The English Ariosto: The Elizabethan Poet and the Marvellous', Studies in Philology, 80.3 (1983), 277-99

Lees-Jeffries, Hester, 'From the Fountain to the Well: Redcrosse Learns to Read', Studies in Philology, 100.2 (2003), 135-76

Lefebvre, Henri, The Production of Space, trans. Donald Nicholson-Smith (Oxford: Blackwell, 1991)

Le Goff, Jacques, The Birth of Purgatory, trans. Arthur Goldhammer (Aldershot: Scholar Press, 1981; repr. 1990)

Le Goff, Jacques, The Medieval Imagination, trans. Arthur Goldhammer (Chicago: University of Chicago Press, 1985; repr. 1992) 
Leslie, Michael, 'Spenser, Sidney and the Renaissance Garden', ELR, 22.1 (1992), 3-36

Lestringant, Frank, Mapping the Renaissance World: The Geographical Imagination in the Age of Discovery, trans. David Fausett (Cambridge: Polity, 1994)

Lethbridge, J.B., ed., Edmund Spenser: New and Renewed Directions (Madison: Fairleigh Dickinson University Press, 2006)

Lethbridge, J.B., 'Raleigh in Books III and IV of The Faerie Queene: The Primacy of Moral Allegory', Studia Neophilologica, 64 (1992), 55-66

Levinson, Stephen C., Space in Language and Cognition: Explorations in Cognitive Diversity (Cambridge: Cambridge University Press, 2003)

Lewis, C.S., The Allegory of Love: A Study in Medieval Tradition (New York: Oxford University Press, 1936; repr. 1958)

Lewis, C.S., The Discarded Image: An Introduction to Medieval and Renaissance Literature (Cambridge: Cambridge University Press, 1964)

Lewis, C.S., English Literature in the Sixteenth Century Excluding Drama (Oxford: Clarendon Press, 1954; repr. 1959)

Lim, Walter S.H., The Arts of Empire: The Poetics of Colonialism from Ralegh to Milton (Newark: University of Delaware Press, 1998)

Linton, Joan Pong, The Romance of the New World: Gender and the Literary Formations of English Colonialism (Cambridge: Cambridge University Press, 1998)

Lionarons, Joyce Tally, 'Magic, Machines, and Deception: Technology in the Canterbury Tales', The Chaucer Review, 27.4 (1993), 377-86

Livingstone, David N., The Geographical Tradition: Episodes in the History of a Contested Enterprise (Oxford: Blackwell, 1993)

Logan, George M. and Gordon Teskey, eds, Unfolded Tales: Essays on Renaissance Romance (Ithaca: Cornell University Press, 1989)

Lupton, Julia Reinhard, 'Home-Making in Ireland: Virgil's Eclogue I and Book VI of The Faerie Queene', Spenser Studies, 8 (1990), 119-45

Lupton, Julia Reinhard, 'Mapping Mutability: or, Spenser's Irish Plot', in Representing Ireland: Literature and the Origins of Conflict, 15341660, ed. Brendan Bradshaw, Andrew Hadfield, and Willy Maley (Cambridge: Cambridge University Press, 1993), pp. 93-115

MacCaffrey, Isabel G., Spenser's Allegory: The Anatomy of Imagination (Princeton: Princeton University Press, 1976)

MacCaffrey, Wallace T., Elizabeth I: War and Politics, 1588-1603 (Princeton: Princeton University Press, 1992) 
Macfarlane, Robert, The Old Ways: A Journey on Foot (London: Penguin, 2012)

Maley, Willy, “"The Name of the Country I have Forgotten”: Remembering and Dismembering in Sir Henry Sidney's Irish Memoir (1583)', in Ireland in the Renaissance, c. 1540-1660, ed. Thomas Herron and Michael Potterton (Dublin: Four Courts Press, 2007), pp. 52-73

Maley, Willy, Salvaging Spenser: Colonisation, Culture and Identity (Basingstoke: Macmillan, 1997)

Maley, Willy, 'Spenser's Languages: Writing in the Ruins of English', in The Cambridge Companion to Spenser, ed. Andrew Hadfield (Cambridge: Cambridge University Press, 2001), pp. 162-79

Maley, Willy, "To Weet to Work Irenaes Franchisement": Ireland in The Faerie Queene', IUR, 26.2 (1996), 303-19

Man, Paul de, 'The Rhetoric of Temporality', in Interpretation: Theory and Practice, ed. Charles S. Singleton (Baltimore: Johns Hopkins University Press, 1969), pp. 173-209.

Mann, Jenny C., Outlaw Rhetoric: Figuring Vernacular Eloquence in Shakespeare's England (Ithaca: Cornell University Press, 2012)

March, Jenny, Cassell Dictionary of Classical Mythology (London: Cassell, 1998; repr. 2002)

Marin, Louis, 'Frontiers of Utopia: Past and Present', Critical Inquiry, 19 (1993), 397-420

Martin, Carol A.N., 'Authority and the Defense of Fiction: Renaissance Poetics and Chaucer's House of Fame', in Refiguring Chaucer in the Renaissance, ed. Theresa M. Krier (Gainesville: University Press of Florida, 1998), pp. 40-65

Martin, Catherine Gimelli, 'Spenser's Neoplatonic Geography of the Passions: Mapping Allegory in the "Legend of Temperance", Faerie Queene, Book II', Spenser Studies, 24 (2009), 269-307

Massey, Doreen, For Space (London: Sage Publications, 2005)

Mazzio, Carla, The Inarticulate Renaissance: Language Trouble in an Age of Eloquence (Philadelphia: University of Pennsylvania Press, 2009)

Mazzola, Elizabeth, The Pathology of the English Renaissance: Sacred Remains and Holy Ghosts (Leiden: Brill, 1998)

McCabe, Richard A., The Pillars of Eternity: Time and Providence in The Faerie Queene (Blackrock: Irish Academic Press, 1989)

McCabe, Richard A., Spenser's Monstrous Regiment: Elizabethan Ireland and the Poetics of Difference (Oxford: Oxford University Press, 2002)

McCabe, Richard A., 'Translated States: Spenser and Linguistic Colonialism', in Edmund Spenser: Essays on Culture and Allegory, ed. 
Jennifer Klein Morrison and Matthew Greenfield (Aldershot: Ashgate, 2000), pp. $67-88$

McGurk, John, The Elizabethan Conquest of Ireland: The 1590s Crisis (Manchester: Manchester University Press, 1997)

McLean, Stuart, "'To Dream Profoundly": Irish Boglands and the Imagination of Matter', Irish Journal of Anthropology, 10.2 (2007), 61-8

McLeod, Bruce, The Geography of Empire in English Literature, 15801745 (Cambridge: Cambridge University Press, 1999; repr. 2009)

McRae, Andrew, 'Fluvial Nation: Rivers, Mobility and Poetry in Early Modern England', ELR, 38.3 (2008), 506-34

McRae, Andrew, Literature and Domestic Travel in Early Modern England (Cambridge: Cambridge University Press, 2009)

Melville, Robert Dundonald, A Manual of the Principles of Roman Law Relating to Persons, Property and Obligations (Edinburgh: Green, 1915)

Mentz, Steve, 'After Sustainability', PMLA, 127.3 (2012), 586-92

Mentz, Steve, At the Bottom of Shakespeare's Ocean (London: Continuum, 2009)

Mentz, Steve, 'Brown', in Prismatic Ecology: Ecotheory Beyond Green, ed. Jeffrey Jerome Cohen (Minneapolis: University of Minnesota Press, 2013), pp. 193-212

Mentz, Steve, Shipwreck Modernity: Ecologies of Globalization, 15501719 (Minneapolis: University of Minnesota Press, 2015)

Michael, Erika, The Drawings by Hans Holbein the Younger for Erasmus' 'Praise of Folly' (New York: Garland, 1985)

Michelet, Fabienne L., Creation, Migration, and Conquest: Imaginary Geography and Sense of Space in Old English Literature (Oxford: Oxford University Press, 2006)

Miller, David Lee, The Poem's Two Bodies: The Poetics of the 1590 Faerie Queene (Princeton: Princeton University Press, 1988)

Miller, Shannon, Invested With Meaning: The Raleigh Circle in the New World (Philadelphia: University of Pennsylvania Press, 1998)

Miller, T.S., 'Writing Dreams to Good: Reading as Writing and Writing as Reading in Chaucer's Dream Visions', Style, 45.3 (2011), 528-48

Mitchell, W.J.T., 'Preface to the Second Edition of Landscape and Power:

Space, Place and Landscape', in Landscape and Power, ed. W.J.T. Mitchell (Chicago: University of Chicago Press, 2002), pp. vii-xii Mitchell, W.J.T., 'Spatial Form in Literature: Toward a General Theory', Critical Inquiry, 6 (1980), 539-67 
Mohsen, Emilien, Time and the Calendar in Edmund Spenser's Poetical Works (Paris: Publibook, 2005)

Monmonier, Mark S., Coast Lines: How Mapmakers Frame the World and Chart Environmental Change (Chicago: University of Chicago Press, 2008)

Monmonier, Mark S., How to Lie with Maps (Chicago: University of Chicago Press, 1991)

Montiglio, Silvia, Wandering in Ancient Greek Culture (Chicago: University of Chicago Press, 2005)

Montrose, Louis, 'Spenser and the Elizabethan Political Imaginary', ELH, 69.4 (2002), 907-46

Moody, T.W., F.X. Martin, and F.J. Byrne, eds, A New History of Ireland: Early Modern Ireland 1534-1691 (Oxford: Oxford University Press, 2009)

Moore Smith, G.C., ed., Gabriel Harvey's Marginalia (Stratford-UponAvon: Shakespeare Head Press, 1913)

Morrison, Jennifer Klein and Matthew Greenfield, eds, Edmund Spenser: Essays on Culture and Allegory (Aldershot: Ashgate, 2000)

Mullally, Evelyn, The Artist at Work: Narrative Technique in Chrétien de Troyes (Philadelphia: American Philosophical Society, 1988)

Munro, Lucy, Archaic Style in English Literature, 1590-1674 (Cambridge: Cambridge University Press, 2013)

Murphy, Andrew, But the Irish Sea Betwixt Us: Ireland, Colonialism, and Renaissance Literature (Lexington: University Press of Kentucky, 1999)

Murrin, Michael, The Allegorical Epic: Essays in its Rise and Decline (Chicago: University of Chicago Press, 1980)

Murrin, Michael, 'The Rhetoric of Fairyland', in The Rhetoric of Renaissance Poetry From Wyatt to Milton, ed. Thomas O. Sloan and Raymond B. Waddington (Berkeley: University of California Press, 1974), pp. 73-95

Murrin, Michael, The Veil of Allegory: Some Notes Toward a Theory of Allegorical Rhetoric in the English Renaissance (Chicago: University of Chicago Press, 1969)

Murtaugh, Daniel M., 'The Garden and the Sea: The Topography of The Faerie Queene, III', ELH, 40.3 (1973), 325-38

Myers, Benjamin P., 'The Green and Golden World: Spenser's Rewriting of the Munster Plantation', ELH, 76.2 (2009), 473-90

Nellist, Brian, 'The Allegory of Guyon's Voyage: An Interpretation', ELH, 30.2 (1963), 89-106 
Neuse, Richard, 'Book VI as Conclusion to The Faerie Queene, ELH, 35.3 (1968), 329-53

Newcomb, Lori Humphrey, Reading Popular Romance in Early Modern England (New York: Columbia University Press, 2002)

Nicholson, Catherine, 'Othello and the Geography of Persuasion', ELR, 40.1 (2010), 56-87

Nicholson, Catherine, Uncommon Tongues: Eloquence and Eccentricity in the English Renaissance (Philadelphia: University of Pennsylvania Press, 2014)

Nicolson, Marjorie Hope, The Breaking of the Circle: Studies in the Effect of the 'New Science' upon Seventeenth-Century Poetry (New York: Columbia University Press, 1960)

Nievergelt, Marco, Allegorical Quests from Deguileville to Spenser (Cambridge: D.S. Brewer, 2012)

Nohrnberg, James, The Analogy of The Faerie Queene (Princeton: Princeton University Press, 1976)

Nohrnberg, James, 'Britomart's Gone Abroad to Brute-land, Colin Clout's Come Courting from the Salvage Ire-Land: Exile and the Kingdom in Some of Spenser's Fictions for "Crossing Over"', in Edmund Spenser: New and Renewed Directions, ed. J.B. Lethbridge (Madison: Fairleigh Dickinson University Press, 2006), pp. 214-85

Nohrnberg, James, 'Raleigh in Ruins, Raleigh on the Rocks: Sir Wa'ter's Two Books of Mutabilitie and their Subject's Allegorical Presence in Select Spenserian Narratives and Complaints', in Literary and Visual Ralegh, ed. Christopher M. Armitage (Manchester: Manchester University Press, 2013), pp. 31-88

Núñez, Rafael and Kensy Cooperrider, 'The Tangle of Space and Time in Human Cognition', Trends in Cognitive Sciences, 17.5 (2013), 220-9.

O'Keeffe, Tadhg, 'Plantation-era Great Houses in Munster: A Note on Sir Walter Raleigh's House and Its Context', in Ireland in the Renaissance, c. 1540-1660, ed. Thomas Herron and Michael Potterton (Dublin: Four Courts Press, 2007), pp. 274-88

O'Neill, Timothy, Merchants and Mariners in Medieval Ireland (Dublin: Irish Academic Press, 1987)

Oram, William A., 'Spenserian Paralysis', SEL, 41.1 (2001), 49-70

Oram, William A., 'What Did Spenser Really Think of Sir Walter Ralegh When He Published the First Installment of The Faerie Queene?', Spenser Studies, 15 (2001), 165-74

Orgel, Stephen, 'Margins of Truth', in The Renaissance Text: Theory, 
Editing, Textuality, ed. Andrew Murphy (Manchester: Manchester University Press, 2000), pp. 91-107

Orgelfinger, Gail, 'Introduction', in The Hystorye of Olyuer of Castylle (New York: Garland Publishing, 1988), pp. ix-xxxvi

Ortony, Andrew, ed., Metaphor and Thought (Cambridge: Cambridge University Press, 1979; repr. 1980)

Osgood, Charles G., 'Comments on the Moral Allegory of The Faerie Queene', MLN, 46.8 (1931), 502-7

Outhwaite, R.B., 'Dearth, the English Crown and the "Crisis of the 1590s", in The European Crisis of the 1590s: Essays in Comparative History, ed. Peter Clark (London: Allen \& Unwin, 1985), pp. 23-43

Owen, Hywel Wyn and Richard Morgan, Dictionary of the Place-Names of Wales (Llandysul: Gomer, 2007)

Owens, Judith, Enabling Engagements: Edmund Spenser and the Poetics of Patronage (Montreal: McGill-Queen's University Press, 2002)

Padrón, Ricardo, 'Mapping Imaginary Worlds', in Maps: Finding Our Place in the World, ed. J. R. Akerman (Chicago: University of Chicago Press, 2007), pp. 255-88

Palmer, Patricia, Language and Conquest in Early Modern Ireland: English Renaissance Literature and Elizabethan Imperial Expansion (Cambridge: Cambridge University Press, 2001)

Palmer, Patricia, The Severed Head and the Grafted Tongue: Literature, Translation and Violence in Early Modern Ireland (Cambridge: Cambridge University Press, 2013)

Palmer, Patricia, 'Where Does It Hurt? How Pain Makes History in Early Modern Ireland', in The Body in Pain in Irish Literature and Culture, ed. Fionnuala Dillane, Naomi McAreavey, and Emilie Pine (Basingstoke: Palgrave Macmillan, 2016), pp. 21-38

Park, Katherine, 'Bacon's "Enchanted Glass"', Isis, 75.2 (1984), 290-302

Parker, Patricia A., Inescapable Romance: Studies in the Poetics of a Mode (Princeton: Princeton University Press, 1979)

Parker, Patricia A., Shakespeare from the Margins: Language, Culture, Context (Chicago: University of Chicago Press, 1996)

Parry, Glyn, 'John Dee and the Elizabethan British Empire in its European Context', The Historical Journal, 49.3 (2006), 643-75

Parry, Joseph D., 'Phaedria and Guyon: Travelling Alone in The Faerie Queene, Book II', Spenser Studies, 15 (2001), 53-77

Paster, Gail Kern, 'Becoming the Landscape: The Ecology of the Passions in the Legend of Temperance', in Environment and Embodiment 
in Early Modern England, ed. Mary Floyd-Wilson and Garrett A. Sullivan, Jr. (Basingstoke: Palgrave Macmillan, 2007), pp. 137-52

Paster, Gail Kern, The Body Embarrassed: Drama and the Disciplines of Shame in Early Modern England (New York: Cornell University Press, 1993)

Paster, Gail Kern, Humouring the Body: Emotions and the Shakespearean Stage (Chicago: University of Chicago Press, 2004)

Patch, Howard Rollin, The Other World: According to Descriptions in Medieval Literature (Cambridge, MA: Harvard University Press, 1950)

Patterson, Lee, "What Man Artow?" Authorial Self-Definition in The Tale of Sir Thopas and The Tale of Melibee', Studies in the Age of Chaucer, 11 (1989), 117-75

Paxman, David B., Voyage into Language: Space and the Linguistic Encounter, 1500-1800 (Aldershot: Ashgate, 2003)

Perec, Georges, Species of Spaces and Other Pieces, ed. and trans. John Sturrock (London: Penguin, 1997; repr. 1999)

Peters, Jeffrey N., Mapping Discord: Allegorical Cartography in Early Modern French Writing (Newark: University of Delaware Press, 2004) Peterson, Kaara L., 'Fluid Economies: Portraying Shakespeare's Hysterics', Mosaic, 34.1 (2001), 35-59

Piehler, Paul, The Visionary Landscape: A Study in Medieval Allegory (London: Edward Arnold, 1971)

Pinet, Simone, Archipelagoes: Insular Fictions from Chivalric Romance to the Novel (Minneapolis: University of Minnesota Press, 2011)

Porges Watson, E.A.F., 'Mutabilitie's Debateable Land: Spenser's Ireland and the Frontiers of Faerie', in Edmund Spenser: New and Renewed Directions, ed. J.B. Lethbridge (Madison: Fairleigh Dickinson University Press, 2006), pp. 286-301

Porter, Philip W. and Fred E. Lukermann, 'The Geography of Utopia', in Geographies of the Mind: Essays in Historical Geosophy, ed. David Lowenthal and Martyn J. Bowden (New York: Oxford University Press, 1976), pp. 197-223

Powrie, Sarah, 'Spenser's Mutabilitie and the Indeterminate Universe', SEL, 53.1 (2013), 73-89

Pratt, Mary Louise, Imperial Eyes: Travel Writing and Transculturation (London: Routledge, 1992; repr. 1998)

Prendergast, Thomas A., Poetical Dust: Poets' Corner and the Making of Britain (Philadelphia: University of Pennsylvania Press, 2015)

Prendergast, Thomas A., 'Spenser's Phantastic History, The Ruines 
of Time, and the Invention of Medievalism', JMEMS, 38.2 (2008), 175-96

Pugh, Syrithe, 'Acrasia and Bondage: Guyon's Perversion of the Ovidian Erotic in Book II of The Faerie Queene', in Edmund Spenser: New and Renewed Directions, ed. J.B. Lethbridge (Madison: Fairleigh Dickinson University Press, 2006), pp. 153-94

Pugh, Syrithe, Spenser and Ovid (Aldershot: Ashgate, 2005)

Putter, Ad, An Introduction to The Gawain Poet (London: Longman, 1996)

Putter, Ad, 'The Landscape of Courtly Romance', in Sir Gawain and the Green Knight and French Arthurian Romance (Oxford: Clarendon Press, 1995; repr. 2001)

Quilligan, Maureen, The Language of Allegory: Defining the Genre (Ithaca:

Cornell University Press, 1979; repr. 1992)

Quilligan, Maureen, Milton's Spenser: The Politics of Reading (Ithaca:

Cornell University Press, 1983)

Quinn, D.B., 'Renaissance Influence in English Colonization', TRHS, 26 (1976), 73-93

Quint, David, Epic and Empire: Politics and Generic Form from Virgil to Milton (Princeton: Princeton University Press, 1993)

Quitslund, Jon A., Spenser's Supreme Fiction: Platonic Natural Philosophy and The Faerie Queene (Toronto: University of Toronto Press, 2001)

Rabkin, Eric S., 'Spatial Form and Plot', Critical Inquiry, 4 (1977), 253-70 Rajan, Balachandra, The Form of the Unfinished: English Poetics from Spenser to Pound (Princeton: Princeton University Press, 1985)

Ramachandran, Ayesha, The Worldmakers: Global Imagining in Early

Modern Europe (Chicago: University of Chicago Press, 2015)

Rambo, Elizabeth L., Colonial Ireland in Medieval English Literature (Selinsgrove: Susquehanna University Press, 1994)

Rathborne, Isabel E., The Meaning of Spenser's Fairyland (New York:

Columbia University Press, 1937)

Read, David, Temperate Conquests: Spenser and the Spanish New World (Detroit: Wayne State University Press, 2000)

Reichert, Dagmar, 'On Boundaries', Environment and Planning D: Society and Space, 10.1 (1992), 87-98

Reif-Hulser, Monika, ed., Borderlands: Negotiating Boundaries in PostColonial Writing (Amsterdam: Rodopi, 1999)

Reiss, Timothy J., Knowledge, Discovery, and Imagination in Early Modern Europe: The Rise of Aesthetic Rationalism (Cambridge: Cambridge University Press, 1997) 
Relihan, Constance C., Cosmographical Glasses: Geographic Discourse, Gender, and Elizabethan Fiction (Kent, OH: Kent State University Press, 2004)

Remien, Peter, 'Silvan Matters: Error and Instrumentality in Book I of The Faerie Queene', Spenser Studies, 27 (2013), 119-43

Rhodes, William, 'Chaucer in Ireland: Archaism, Etymology, and the Idea of Development', in Rereading Chaucer and Spenser: Dan Geffrey with the New Poete, ed. Rachel Stenner, Tamsin Badcoe, and Gareth Griffith (Manchester: Manchester University Press, 2019), pp. 98-112 Rigolot, François, 'The Renaissance Fascination with Error: Mannerism and Early Modern Poetry', RQ, 57.4 (2004), 1219-34

Roche, Jr., Thomas P., The Kindly Flame: A Study of the Third and Fourth Books of Spenser's Faerie Queene (Princeton: Princeton University Press, 1964)

Rosenfeld, Colleen Ruth, Indecorous Thinking: Figures of Speech in Early Modern Poetics (New York: Fordham University Press, 2018)

Ross, Charles Stanley, The Custom of the Castle: From Malory to Macbeth (Berkeley: University of California Press, 1997)

Roszak, Theodore, Where the Wasteland Ends: Politics and Transcendence in Postindustrial Society (Berkeley: Celestial Arts, 1989)

Rouse, Robert, 'Walking (between) the Lines: Romance as Itinerary / Map', in Medieval Romance, Medieval Contexts, ed. Rhiannon Purdie and Michael Cichon (Cambridge: D.S. Brewer, 2011), pp. 135-48

Rudick, Michael, 'Three Views on Ralegh and Spenser: A Comment', Spenser Studies, 15 (2001), 197-203

Ruvoldt, Maria, The Italian Renaissance Imagery of Inspiration (Cambridge: Cambridge University Press, 2004)

Russell, John L., 'The Copernican System in Great Britain', in The Reception of Copernicus' Heliocentric Theory, ed. Jerzy Dobrzycki (Dordrecht: Reidel, 1972), pp. 189-239

Sadowski, Piotr, 'Spenser's "Golden Squire" and "Golden Meane": Numbers and Proportions in Book II of The Faerie Queene', Spenser Studies, 14 (2000), 107-31

Said, Edward W., Culture and Imperialism (London: Vintage, 1994)

Said, Edward W., Orientalism (London: Penguin, 1978; repr. 2003)

Salamon, Linda Bradley, 'The Imagery of Roger Ascham', Texas Studies in Literature and Language, 15.1 (1973), 5-23

Sanchez, Melissa E., Erotic Subjects: The Sexuality of Politics in Early Modern English Literature (Oxford: Oxford University Press, 2011) 
Sanford, Rhonda Lemke, Maps and Memory in Early Modern England: A Sense of Place (New York: Palgrave, 2002)

Santore, Cathy, 'The Tools of Venus', Renaissance Studies, 11.3 (1997), 179-207

Saunders, Angharad, 'Literary Geography: Reforging the Connections',

Progress in Human Geography, 34.4 (2010), 436-52

Saunders, Corinne J., The Forest of Medieval Romance: Avernus, Broceliande, Arden (Cambridge: D.S. Brewer, 1993)

Scafi, Alessandro, Mapping Paradise: A History of Heaven on Earth (Chicago: University of Chicago Press, 2006)

Schilder, Günter, The Netherland Nautical Cartography from 1550 to 1650 (Lisboa: Instituto de Investigação Científica Tropical, 1984)

Schoenfeldt, Michael C., Bodies and Selves in Early Modern England: Physiology and Inwardness in Spenser, Shakespeare, Herbert, and Milton (Cambridge: Cambridge University Press, 1999)

Schwyzer, Philip, Archaeologies of English Renaissance Literature (Oxford: Oxford University Press, 2007)

Schwyzer, Philip and Simon Mealor, Archipelagic Identities: Literature and Identity in the Atlantic Archipelago, 1550-1800 (Aldershot: Ashgate, 2004)

Seelig, Sharon Cadman, “'Speake, That I May See Thee”: The Styles of Sir Thomas Browne', in Sir Thomas Browne: The World Proposed, ed. Reid Barbour and Claire Preston (Oxford: Oxford University Press, 2008), pp. 13-35

Sherman, William H., John Dee: The Politics of Reading and Writing in the English Renaissance (Amherst: University of Massachusetts Press, 1995)

Short, John Rennie, Making Space: Revisioning the World, 1475-1600

(New York: Syracuse University Press, 2004)

Shuger, Debora K., Habits of Thought in the English Renaissance: Religion,

Politics, and the Dominant Culture (Toronto: University of Toronto Press, 1997)

Siewers, Alfred K., 'Spenser's Green World', Early English Studies, 3 (2010), 1-34

Siewers, Alfred K., Strange Beauty: Ecocritical Approaches to Early Medieval Landscape (Basingstoke: Palgrave Macmillan, 2009)

Silberman, Lauren, Transforming Desire: Erotic Knowledge in Books III and IV of The Faerie Queene (Berkeley: University of California Press, 1995)

Smith, Donald Kimball, The Cartographic Imagination in Early Modern 
England: Rewriting the World in Marlowe, Spenser, Raleigh and Marvell (Aldershot: Ashgate, 2008)

Smith, Helen and Louise Wilson, eds, Renaissance Paratexts (Cambridge: Cambridge University Press, 2011)

Smith, Jonathan M., 'Geographical Rhetoric: Modes and Tropes of Appeal', Annals of the Association of American Geographers, 86.1 (1996), 1-20

Smith, Pamela H., The Body of the Artisan: Art and Experience in the Scientific Revolution (Chicago: University of Chicago Press, 2004)

Smith, Roland M., 'Spenser's Irish River Stories', PMLA, 50.4 (1935), pp. 1047-56

Smith, Roland M., 'Spenser's Tale of the Two Sons of Milesio', $M L Q, 3$ (1942), pp. 547-57

Smyth, Gerry, Space and the Irish Cultural Imagination (Basingstoke: Palgrave, 2001)

Smyth, William J., Map Making, Landscapes and Memory: A Geography of Colonial and Early Modern Ireland, c. 1530-1750 (Cork: Cork University Press, 2006)

Snyder, Susan, 'Guyon the Wrestler', Renaissance News, 14.4 (1961), 249-52

Sobecki, Sebastian I., The Sea and Medieval English Literature (Cambridge: D.S. Brewer, 2008)

Soja, Edward W., Postmodern Geographies: The Reassertion of Space in Critical Social Theory (London: Verso, 1989; repr. 1999)

Spearing, A.C., Medieval Dream-Poetry (Cambridge: Cambridge University Press, 1976)

Spiller, Elizabeth, Science, Reading, and Renaissance Literature: The Art of Making Knowledge, 1580-1670 (Cambridge: Cambridge University Press, 2004; repr. 2007)

Spirn, Anne Whiston, The Language of Landscape (New Haven: Yale University Press, 1998)

Stallybrass, Peter, 'Robin Hood, the Carnivalesque and the Rhetoric of Violence', in The Violence of Representation: Literature and the History of Violence, ed. Nancy Armstrong and Leonard Tennenhouse (London: Routledge, 1989), pp. 45-76

Stanbury, Sarah, Seeing the Gawain Poet: Description and the Act of Perception (Philadelphia: University of Pennsylvania Press, 1991)

Steadman, John M., The Hill and the Labyrinth: Discourse and Certitude in Milton and His Near-Contemporaries (Berkeley: University of California Press, 1984) 
Steggle, Matthew, 'Charles Chester and Richard Hakluyt', SEL, 43.1 (2003), 65-81

Stenner, Rachel, Tamsin Badcoe, and Gareth Griffith, eds, Rereading Chaucer and Spenser: Dan Geffrey with the New Poete (Manchester: Manchester University Press, 2019)

Stern, Paul, Knowledge and Politics in Plato's Theaetetus (Cambridge: Cambridge University Press, 2008)

Stern, Virginia F., Gabriel Harvey: His Life, Marginalia and Library (Oxford: Clarendon Press, 1979)

Stevens, John E., Medieval Romance: Themes and Approaches (London: Hutchinson, 1973)

Stillman, Robert E., "Words Cannot Knytt": Language and Desire in Ralegh's The Ocean to Cynthia', SEL, 27.1 (1987), 35-51

Sullivan, Jr., Garrett, Sleep, Romance and Human Embodiment (Cambridge: Cambridge University Press, 2012)

Summers, David A., Spenser's Arthur: The British Arthurian Tradition and The Faerie Queene (Lanham: University Press of America, 1997)

Sutton, James M., Materializing Space at an Early Modern Prodigy House: The Cecils at Theobalds, 1564-1607 (Aldershot: Ashgate, 2004)

Szönyi, György E., 'Paracelsus, Scrying and the Lingua Adamica: Contexts for John Dee's Angel Magic', in John Dee: Interdisciplinary Studies in English Renaissance Thought, ed. Stephen Clucas (Dordrecht: Springer, 2006), pp. 207-29

Taylor, E.G.R., The Haven Finding Art: A History of Navigation from Odysseus to Captain Cook (London: Hollis and Carter, 1956)

Taylor, E.G.R., Late Tudor and Early Stuart Geography 1583-1650 (London: Methuen, 1934)

Taylor, E.G.R., 'A Letter Dated 1577 from Mercator to John Dee', Imago Mundi, 13.1 (1956), 56-68

Teskey, Gordon, Allegory and Violence (Ithaca: Cornell University Press, 1996)

Teskey, Gordon, 'From Allegory to Dialectic: Imagining Error in Spenser and Milton', PMLA, 101.1 (1986), 9-23

Teskey, Gordon, 'Notes on Reading The Faerie Queene: From Moment to Moment', in Spenser in the Moment, ed. Paul J. Hecht and J.B. Lethbridge (Madison: Fairleigh Dickinson University Press, 2015), pp. 217-34

Thomas, Charles, 'Lundy's Lost Name', in Island Studies: Fifty Years of the Lundy Field Society, ed. R.A. Irving, A.J. Schofield, and C.J. Webster (Bideford: Lazarus Press for The Lundy Field Society, 1997), pp. 29-37 
Tonkin, Humphrey, 'Spenser's Garden of Adonis and Britomart's Quest', PMLA, 88.3 (1973), 408-17

Trinkaus, Charles, 'Protagoras in the Renaissance: An Exploration', in Philosophy and Humanism: Renaissance Essays in Honour of Paul Oskar Kristeller, ed. Edward P. Mahoney (Leiden: E.J. Brill, 1976), pp. 190-213

Tuan, Yi-Fu, The Hydrologic Cycle and the Wisdom of God: A Theme in Geoteleology (Toronto: University of Toronto Press, 1968)

Turchi, Peter, Maps of the Imagination: The Writer as Cartographer (Texas: Trinity University Press, 2004)

Turner, Henry S., The English Renaissance Stage: Geometry, Poetics, and the Practical Spatial Arts 1580-1630 (Oxford: Oxford University Press, 2006; repr. 2010)

Unger, Richard W., Ships on Maps: Pictures of Power in Renaissance Europe (Basingstoke: Palgrave Macmillan, 2010)

Van Es, Bart, Spenser's Forms of History (Oxford: Oxford University Press, 2002)

Vermette, Rosalie, 'Terrae Incantatae: The Symbolic Geography of Twelfth-Century Arthurian Romance', in Geography and Literature: A Meeting of the Disciplines, ed. William E. Mallory and Paul SimpsonHousley (Syracuse: Syracuse University Press, 1987), pp. 145-60

Vernant, Jean-Pierre, Myth and Thought Among the Greeks, trans. Janet Lloyd with Jeff Fort (New York: Zone, 2006)

Viktus, Daniel, 'The New Globalism: Transcultural Commerce, Global Systems Theory, and Spenser's Mammon', in A Companion to the Global Renaissance: English Literature and Culture in the Era of Expansion, ed. Jyotsna Singh (Chichester: Wiley-Blackwell, 2009), pp. 31-49

Villeponteaux, Mary, 'Displacing Feminine Authority in The Faerie Queene', SEL, 35.1 (1995), 53-67

Vinaver, Eugène, The Rise of Romance (Oxford: Clarendon Press, 1971) Wallace, David, Premodern Places: Calais to Surinam, Chaucer to Aphra Behn (Oxford: Blackwell, 2004; repr. 2006)

Walsham, Alexandra, The Reformation of the Landscape: Religion, Identity, and Memory in Early Modern Britain and Ireland (Oxford: Oxford University Press, 2011)

Warren, Christopher N., Literature and the Law of Nations, 1580-1680 (Oxford: Oxford University Press, 2015)

Waters, David W., The Art of Navigation in England in Elizabethan and Early Stuart Times (New Haven: Yale University Press, 1958) 
Watt, J.A., 'Gaelic Polity and Cultural Identity', in A New History of Ireland, Volume II: Medieval Ireland 1169-1534, ed. Art Cosgrove (Oxford: Oxford University Press, 2008), pp. 314-51

Weatherby, Harold L., 'Pourd out in Loosnesse', Spenser Studies, 3 (1982), 73-85

Weisl, Angela Jane, Conquering the Reign of Femeny: Gender and Genre in Chaucer's Romance (Cambridge: D.S. Brewer, 1995)

Weiss, Allen S., 'Preface: Gardens of the Imagination', in Mirrors of Infinity: The French Formal Garden and Seventeenth Century Metaphysics (New York: Princeton Architectural Press, 1995), pp. 8-19 Weixel, Elizabeth M., 'Squires of the Wood: The Decline of the Aristocratic Forest in Book VI of The Faerie Queene', Spenser Studies, 25 (2010), 187-213

Werth, Tiffany Jo, The Fabulous Dark Cloister: Romance in England after the Reformation (Baltimore: Johns Hopkins University Press, 2011)

West, Michael, 'Spenser, Everard Digby, and the Renaissance Art of Swimming', $R Q, 26.1$ (1973), 11-22

West, Michael, 'Spenser's Art of War: Chivalric Allegory, Military Technology, and the Elizabethan Mock-Heroic Sensibility', RQ, 41.4 (1988), 654-704

Whitehead, Christiania, Castles of the Mind: A Study of Medieval Architectural Allegory (Cardiff: University of Wales Press, 2003)

Whitfield, Peter, The Charting of the Oceans: Ten Centuries of Maritime Maps (London: British Library, 1996)

Williams, Elizabeth, 'England, Ireland and Iberia in Olyver of Castylle: The View from Burgundy', in Boundaries in Medieval Romance, ed. Neil Cartlidge (Cambridge: D.S. Brewer, 2008), pp. 93-102

Williams, Kathleen, 'Spenser: Some Uses of the Sea and the Storm-tossed Ship', in Research Opportunities in Renaissance Drama, XIII-XIV, ed. S. Schoenbaum (Evanston: Northwestern University Press, 1970-71), pp. 135-42

Williams, Kathleen, Spenser's Faerie Queene: The World of Glass (London: Routledge and Kegan Paul, 1966)

Williams, Kathleen, 'Venus and Diana: Some Uses of Myth in The Faerie Queene', ELH, 28.2 (1961), 101-20

Williams, Wes, Pilgrimage and Narrative in the French Renaissance: 'The Undiscovered Country' (Oxford: Clarendon, 1998)

Wilson Knight, G., 'The Spenserian Fluidity', in Elizabethan Poetry: Modern Essays in Criticism, ed. Paul J. Alpers (Oxford: Oxford University Press, 1967), pp. 329-44 
Wofford, Susanne Lindgren, 'Britomart's Petrarchan Lament: Allegory and Narrative in The Faerie Queene III, iv', Comparative Literature, 39.1 (1987), 28-57

Wofford, Susanne Lindgren, The Choice of Achilles: The Ideology of Figure in the Epic (Stanford: Stanford University Press, 1992)

Wofford, Susanne Lindgren, 'Gendering Allegory: Spenser's Bold Reader and the Emergence of Character in The Faerie Queene III', Criticism, 30.1 (1988), 1-22

Wolfe, Jessica, Humanism, Machinery, and Renaissance Literature (Cambridge: Cambridge University Press, 2004)

Woodcock, Matthew, Fairy in The Faerie Queene: Renaissance ElfFashioning and Elizabethan Myth-Making (Aldershot: Ashgate, 2004) Woods, William F., Chaucerian Spaces: Spatial Poetics in Chaucer's Opening Tales (Albany: State University of New York Press, 2008)

Woolway, Joanne, 'Spenser and the Culture of Place', Guest Lecture: University of Oslo, 17 April 1996. Archived by EMLS at http://extra. shu.ac.uk/emls/iemls/conf/texts/woolway.html (last accessed 2 June 2016)

Wright, John K., The Geographical Lore of the Time of the Crusades: A Study in the History of Medieval Science and Tradition in Western Europe (New York: American Geographical Society, 1925)

Wright, John K., 'Terrae Incognitae: The Place of the Imagination in Geography', Annals of the Association of American Geographers, 37.1 (1947), 1-15

Yarnall, Judith, Transformations of Circe: The History of an Enchantress (Chicago: University of Illinois Press, 1994)

Yates, Frances A., The Art of Memory (Chicago: University of Chicago Press, 1966)

Yates, Frances A., Astraea: The Imperial Theme in the Sixteenth Century (London: Routledge and Kegan Paul, 1975)

Yates, Frances A., Giordano Bruno and the Hermetic Tradition (London: Routledge, 2002)

Yates, Frances A., The Occult Philosophy in the Elizabethan Age (London: Routledge, 1979)

Yates, Julian, Error, Misuse, Failure: Object Lessons from the English Renaissance (Minneapolis: University of Minnesota Press, 2003)

Yeats, W.B., The Cutting of an Agate, in Essays and Introductions (London: Macmillan, 1961; repr. 1980)

Zurcher, Andrew, Edmund Spenser's The Faerie Queene: A Reading Guide (Edinburgh: Edinburgh University Press, 2011) 
Zurcher, Andrew, 'Printing The Faerie Queene in 1590', Studies in Bibliography, 57 (2005), 115-50

Zurcher, Andrew, Spenser's Legal Language: Law and Poetry in Early Modern England (Cambridge: Cambridge University Press, 2012) 